\title{
İstanbul Esenyurt'taki Suriyelilere İlişkin Medya Analizi*
}

\author{
Media Analysis of Syrians in Esenyurt, Istanbul
}

\section{Gülsün SARIOĞLU}

Doktorant, İletişim Uzmanı/Yönetmen, İstanbul Üniv., S.B.E., gulsunsarioglu@gmail.com

Radyo - Televizyon ve Sinema A.B.D.,

https://orcid.org/0000-0002-1841-0943
Makale Başvuru Tarihi / Received: 13.01.2019

Makale Kabul Tarihi / Accepted: 30.03.2019

Makale Türü / Article Type: Araştırma Makalesi

\section{Anahtar \\ Kelimeler: \\ Mülteci, \\ Öteki, \\ Suriye'li, \\ Türkiye'nin Misafirleri,}

Keywords:

Refugee,

The Other,

Syrian,

Guests Of Turkev,

\section{ÖZET}

Suriye'de 2011 yılında başlayan iç savaştan kaçan mülteciler, kitleler halinde Türkiye'ye sığınmak zorunda kalmıştır. Türkiye'nin Suriyelilere dönük göçmen politikası, savaşın başladığ ilk süreçten itibaren açık kapı politikası şeklinde ilerlemiştir. Türkiye'ye geçici olarak yerleşen mülteciler, Suriye'de savaşın beklenenden uzun sürmesi sebebi ile kalıcı bir göçmen nüfusa dönüşmüşür. Türkiye'ye gelen yaklaşık 3,5 milyon Suriyeli mültecinin yüzde 92 'si, Türkiye'nin hemen her yerinde şehir merkezlerinde toplumla bir arada yaşayan kent mültecileri haline gelmiştir. Türkiye'nin içinde bulunduğu sosyo - ekonomik şartlarl düşündüğümüzde, Suriyeliler ile uzun vadede bir arada yaşayabilmenin koşullar ve entegrasyon sürecine dair yapılan çalışmalar oldukça önem teşkil etmektedir. Suriyelilerin illere göre dağgllımında, 484.505 kayttl Suriyeli mülteci ile İstanbul birinci sırada yer almaktadır. Suriyelilerin, istihdam olanaklarının daha fazla olduğu Avrupa yakasında yaşamayı tercih ettiği görülmektedir. En fazla mülteci barındıran ilçelerden biri olan Esenyurt, çok saylda mülteciye ev sahipliği yapmaktadır. İstanbul'un önemli sanayi bölgelerinden Esenyurt özelinde yaptığımız çalışmamızda, burada yaşayan Suriyeli mültecilerin özgün deneyimlerine bakılmış ve yerel halkın mülteciler konusundaki tutumları analiz edilmiştir. Yerel halkın, neredeyse her gün etkileşim içerisinde olduğu Suriyeli mültecilerle birlikte yaşama sürecinde; karşılaştıkları sorunlar ve sıkıntılara değinilmiştir.Alan yazınına paralel olarak, bu çalışmanın sonuçları; Esenyurt'ta yaşamını devam ettiren Suriyeli mültecilerin, yerel halk tarafindan çoğunlukla ötekileştirildiğini, dışlandığını göstermektedir. Esenyurt'ta mülteci nüfusunun çok fazla olması nedeniyle birtakım mekansal problemlerin ortaya çıtığ görülmektedir. Medyada Esenyurt'la ilgili çıkan haberlerin, yerel halk ve Suriyeliler üzerinde oldukça etkili olduğu sonucuna varılmiştır.

\begin{abstract}
Refugees who escaped from the civil war began in 2011 in Syria had to take refuge in Turkey en masse. Turkey's immigration policy from the first process in which the war began has progressed as an open door policy. As the war in Syria took longer than expected refugees settled temporarily in Turkey has turned into a permanent immigrant population. 92 percent of 3,5 million Syrian refugees in Turkey has become urban refugees living together with society. Considering Turkey's socio-economic conditions which Turkey in, the studies on the conditions of on the long-term coexistence and integration process has became more important. According to their distribution in İstanbul province is ranked in the first place with 484.505 registered Syrian refugees. It seems that most of the Syrians refuges live on the European side, where employment opportunities are higher. Esenyurt, one of the most refugee-bearing cities, is home to a large number of refugees. In our study in Esenyurt, which is one of the important industrial regions of Istanbul, the unique experiences of the Syrian refugees living here were analyzed and the attitudes of the local people toward the refugees were analyzed. The problems and troubles encountered by the local people in the process of living together with the Syrian refugees, who are interacting almost every day, have been addressed. In parallel with the related literature, the findings of this study point out; that the Syrian refugees who continued their life in Esenyurt were mostly alienated and excluded by local peopleIt is seen that a number of spatial problems have arisen due to a large number of the refugee population in Esenyurt. It was concluded the news about Esenyurt in the media was very influential on local people and Syrians.
\end{abstract}

* Bu makale İstanbul Yeni Yüzyıl Üniversitesi'nde Doç. Dr. Remziye KÖSE ÖZELÇi் danışmanlığında hazırlanan “Türkiyenin Misafirleri Suriyeli Mültecilerin Öteki Bağlamında Göçmen Deneyimi: Esenyurt Örneği’” adlı yüksek lisans tezinden üretilmiştir. 


\section{GIRISS}

İnsanlık tarihinin başlangıcından itibaren insanlığa değer katan her şey göçler aracılığıyla meydana gelmiştir. Belirli bir uzaklıkta ve belirli bir zaman diliminde etkisini gösteren tüm değişim yönelimleri, "göç" şeklinde tanımlanmaktadır (Erder, 1986:9). Göç hareketleri incelendiğinde; savaşların, siyasi ve etnik çatışmaların, iklim ve ekonomik değişkenlerin toplu göç yaşantılarının en önemli sebepleri arasında olduğu görülmektedir. $\mathrm{Bu}$ sebeplerle dünyada milyonlarca insan kendi ülkelerinden ayrılarak başka yerlerde yaşamak zorunda kalmıştır. Farklı kültürlere sahip birey ve grupların etkileşime girmesiyle taşınan "maddi ve manevi değerlerin de yer değişmesi” sonucunda kültürleşmeler meydana gelmiştir (Güvenç, 1999:122).

Mücbir sebeplerle (tabi afet, savaş, sürgün vb. gibi) bireylerin yaşam alanlarını terk etmek zorunda kalmaları veya terk etmeye mecbur bırakılmaları sonucuyla oluşan göç; "zorunlu göç" şeklinde tanımlanmaktadır. Göçmenlik, insanların yurtlarından ayrılarak daha iyi yaşam olanakları bulmak umuduyla başka yerlere hareket etme halidir. İnsanlar, tarihin her döneminde göç etmek zorunda kalmıştır (Barnes, 2001; Beter, 2006; Gün, 2006; Li ve Teixeira, 2007; Marsella ve Ring, 2003; Sundquist, 1994). İnsanların yaşadıkları ülkeyi terk etmek zorunda kalması beraberinde gündelik hayatlarını da terk etmelerine neden olmuştur. Bu süreç kültürel sınırların geçildiği, ihlal edildiği, genişletildiği, gündelik hayatın yeniden şekillendirildiği zorunlu ve zorlu bir süreçtir.

Türkiye'nin özel konumu farklı kültürlerden farklı sebeplerle gelen göçmen gruplarına ev sahipliği yapmasına neden olmuştur (İçduygu vd., 2014:222). Türkiye'de özellikle İkinci Dünya Savaşı sonrası yaşanan göç hareketleri, göç ve kitlesel sığınmalarda önemli etkiye sahiptir. 1922-1945 seneleri arasında Yunanistan, Balkanlar ve Almanya'dan 1 milyonun üzerinde göçmenin Türkiye'ye giriş yapması, 1988-2000 seneleri arasında Irak, Bulgaristan, Bosna ve Kosova'dan 900 bin göçmenin gelmesi ile Türkiye milyonlarca göçmene ev sahipliği yapmıştır. Fakat son dönemlerde yaşanan göç hareketinin kapsamı ve niteliği geçmişten farklı izler taşımaktadır.

2011 yılı mart ayında başlayan "Arap Baharı” süreci değişim talebinde bulunan toplumsal hareketin Suriye'ye yansıması ile iç savaşın başlamasına neden olmuş ve yayılarak devam etmiştir. Suriye'nin kuzeyinde başlayan çatışma hali kısa sürede Şam ve Halep'e kadar ulaşmıştır. Türkiye en uzun kara sınırına sahip olan komşusu Suriye hükümeti ile 2011 y1lı başlarında mevcut politik durumun istikrarını koruması için olumlu ilişkiler geliştirmesine rağmen iç savaş hareketliliği başladığı için Türkiye'nin Suriye ilişkileri askıya alınmıştır. Çatışmaların uzaması ve Suriye Devlet Başkanı Beşşar Esad'ın tutumu ve ülkenin çeşitli bölgelerinde isyanların başlayarak iç savaş haline dönüşmesi sebebiyle, Türkiye hükümetinin komşu ülkeye bakış açısı değişmiştir. Yaşanan bu olumsuz süreçten Türkiye hükümeti yoğun bir şekilde etkilenmiştir. Çatışma ortamından ve ülke içerisindeki savaştan kaçan kitleler Türkiye'ye sığınmıştır.

Dünya genelinde en çok Suriyeli mülteci barındıran ülke, yakın geçmişte yaşanan olaylar nedeniyle Türkiye olmuştur. Yoğun bir göç hareketine ev sahipliği yapan Türkiye, bu nedenle "açık kapı" politikası yürütme kararı almıştır. Bu bağlamda, 29 Nisan 2011 yılında Hatay Cilvegözü sınır kapısının önünde hareketliliğin başlamasıyla Türkiye'ye ilk Suriyeli mülteci akını başlamıştır.

Nisan 2011 tarihinden itibaren geride bıraktığımız 7 yıllık süreç içerisinde yaklaşık 3,5 milyon Suriyeli aralıksız bir şekilde Türkiye'ye sığınmıştır. Türkiye, 2013 Nisan ayından itibaren, 6458 Sayılı Yabancılar ve Uluslararası Koruma Kanunu'nu kabul ederek, Türkiye'den korunma talebinde bulunan yabancı, mülteci veya sığınmacıların hukuki statülerini belirlemiştir.

2017 yılı itibariyle, Türkiye'de ikamet eden sığınmacıların rakamı 3.424.237 iken, geçici koruma altındakilerin rakamı ise 2.8 milyondur. İlk etapta kayıt altındaki 258 bin sı̆̆ınmacı ise Türkiye'de yaklaşık 10 şehirde yer alan 21 kamp alanında yaşarken geri kalan çoğunluk ise kamp dışında yaşamayı tercih ederek kent nüfusu haline dönüşmüştür(http://www.goc.gov.tr/icerik/goc-istatistikleri_363_378-2017/). Yerel halkla birlikte kentlerde yaşayan sığınmacıların oranı ise yüzde 92'yi bulmaktadır (Erdoğan, 2017:13). Birleşmiş Milletler Yüksek Komiserliği'nin verilerine göre; İstanbul 558.437 ile toplam mülteci sayısının yüzde 17 'si ile yüzde 25 'i arasındaki nüfusuna ev sahipliği yaparak en fazla mülteciyi barından şehir konumunda birinci sırada yer almaktadır. Sırasıyla 452.534 mülteci nüfusu ile Şanlıurfa ikinci sırada, 447.884 ile Hatay üçüncü sırada yer almaktadir.

Suriyeli mülteciler genellikle ekonomik nedenlerle sanayi bölgelerine doğru göç etmeyi tercih etmektedir. İstanbul, toplumsal kabul sürecine daha duyarlı olduğundan ve çok fazla kültürel çeşitliliği içerisinde barındırdığı için en fazla mültecinin yaşadığı kent konumuna gelmiştir. Suriyelilerin, İstanbul Avrupa yakasının 
belirli ilçelerinde yoğunluk göstermeleri sebebiyle kentin dinamik yapısında değişiklikler oluşmuş ve yeni alt kültürler oluşmuştur.

Göç İdaresi 2016 verilerine göre, İstanbul Avrupa Yakası'nda 6 ilçe (Küçükçekmece, Bağcılar, Fatih, Sultangazi, Esenyurt, Esenler) Anadolu yakasında ise 1 ilçede (Ümraniye) yoğunluk bulunmaktadır. Esenyurt, Suriyeli mültecilere ev sahipliği yapan, kent nüfusunun oranına bakıldığında 25.000 mülteciyi içerisinde barındıran çok fazla sorumluluğu olan bir ilçedir. Esenyurt ilçesinin toplamda 43 mahallesi bulunmaktadır ve Suriyeliler özelikle Kıraç gibi sanayi bölgesi olan kırsal alanlarda yaşamayı tercih etmektedir (http://www.goc.gov.tr-2017/). Gün geçtikçe sayıları artan ve ilçenin neredeyse her yerine dağılan Suriyeli mültecilerin kent nüfusu ile birlikte yaşaması birtakım kentsel problemlerin oluşmasına neden olmaktadır.

Savaşın başladığı ilk süreçten itibaren ilçeye göç etmeye başlayan mülteciler başlangıçta her ne kadar misafir ve geçici nüfus olarak görülse de zamanla kent nüfusu haline dönüşmüşlerdir. Nitekim bu süreç Suriyelilerin yerel halka entegrasyon sürecinde sorun teşkil etmektedir. Suriyelilerin yerel halk ile aralarında dil, kültür ve yaşam tarzının farklı olması kabul ve uyum sürecinin uzamasına neden olmaktadır. Yerel halkla mülteciler arasında zamanla gerilim artmış ve medyada çıkan haberler mültecilere yönelik olumsuz algıyı körüklemiştir.

\section{TÜRKIYY'YE YÖNELIK DIŞ GÖÇLER}

Osmanlı İmparatorluğu'nun karşılaştığı en önemli göç sorunu olarak bilinen "93 Harbi”, 1877-1878 Osmanl1Rus savaşı sürecinde gerçekleşmiştir. Savaş yaşanırken ve savaşın son bulduğu süreçte 1 milyon üzerindeki Osmanlı vatandaşı yer değiştirmek zorunda kalarak mülteci konuma düşmüştür. Göç, özellikle Kuzey Kafkasya, Kırım ve Balkan Türk-Müslüman halkının Anadolu'ya hareketi ile gerçekleşmiştir. Osmanlı İmparatorluğu ağır koşullarla yenilgiyi kabul etmiş ve süreç Osmanlı’nın sonunu getiren kırılma noktası olmuştur. Prof. Dr. Kemal Karpat'ın da "Osmanlı'dan Günümüze Etnik Yapılanma ve Göçler" adlı kitabında gebir yer verdiği bu tarihsel dönem; ilerleyen zamanlarda Cumhuriyet'in ana amaçlarından biri olan 'millet' kavramının şekillenmesinde belirleyici rol oynamıştır (Karpat, 2010:15). Birinci Dünya Savaşı sonralarında da göçler devam etmiştir. Kurtuluş Savaşı ile birlikte mülteci kavramı adeta arka plana itilmiştir. "Göçmen" diye tabir edilen gruplar aynı ırktan, dinden ve dilden olmalarından dolayı Kurtuluş Savaşı'nın ön saflarında yer almışlardır. Böylece; 18 Temmuz 1878'de imzalanan Berlin Anlaşması'yla başlayan göç hareketiyle Osmanlı'nın demografik yapısını değiştiren gruplar, Kurtuluş Savaşına gelindiğinde kendini bu halkın bir parçası kabul ederek bağımsızlık mücadelesi vermiştir. Karşılıklı nüfus mübadeleleri yeni göçmenler getirmiştir. Özellikle, Yunanistan sınırları içerisindeki Türk nüfusu ile yer değiştirme kararı alınmıştır. 1930'ların ikinci yarısından itibaren Avrupa'da faşizmin yükselmesi sonucu Türkiye, bu defa Almanya'da faşizm rüzgârından etkilenen bilim ve kültür insanlarının ülkeye iltica girişimlerine ev sahipliği yapmıştır.

İkinci Dünya Savaşı'nın sona ermesi ve soğuk savaşın başlamasıyla birlikte oluşan süreçte Türkiye'nin mülteci ve sığınmacı sorunu devam etmiştir. İkinci Dünya savaşından 1990 yılına kadar Türkiye'ye yoğunlukla göç hareketi devam etmiş ve yaklaşı 9 milyon insanın göç ettiği hesaplanmıştır (Karpat, 2010:16).

Sovyetler Birliği'nin, "Demir Perde" ülkelerinde ortaya çıkardığı ve 1986'da uygulamaya koyduğu "Yeniden Kurma" ve "Açılık" politikalarının bir ucu yeniden Türkiye'ye dokunmaya başlamıştır. Bu kez senelerden beri yaşanan baskı politikalarına dayanamayan Bulgaristan Türkleri mülteci olarak Türkiye'nin kapısını çalmış ve 300 bin kişi Trakya bölgesinde iskân etmiştir. 1944 yılında S.S.C.B. tarafından Ahıska Türkleri Orta Asya'ya ve Kazakistan'a sürülmüştür. 1989 yılında Özbekistan Fergana'da Ahıska Türklerine ikinci bir sürgün yapılmıştır. Türkiye, bu duruma sessiz kalamayarak Ahıska Türklerinin önemli kısmını ülkeye getirmiştir. Hükümetin kararıyla Ahıska Türklerine Türkiye Cumhuriyeti vatandaşlığı verme işlemleri halen sürmektedir.

1990 yılında patlak veren Birinci Körfez Savaşı Türkiye'nin Güneydoğu sınırlarında hareketliliğe sebep olmuştur. Irak'ın devrik lideri Saddam Hüseyin'in rejiminden ve savaşın zorlu koşullarından kaçan Kuzey Irak Kürtleri ve Türkmenleri sınırın Türkiye tarafina geçmek zorunda kalmıştır. 19. yüzyılın son çeyreğinde başlayan göç ve mülteci hareketliliğinin en kapsamlı dalgasını 2010 yılı sonunda Tunus'ta başlayan, Mısır ve Suriye'ye yayılarak devam eden "Arap Baharı" diye nitelendirilen kaos ve çalkantılar dizisi oluşturmuştur. Türkiye, bu süreçten itibaren açık kapı politikası izlemiş ve Suriyelilere sınır kapılarını açmıştır. 


\subsection{Türkiye'de Göçmen, Mülteci Ve Öteki Algısı}

Göçmen, sığınmacı ve mülteci kavramları sıklıkla birbirine karıştırılmaktadır. Sığınmacı, zorunlu göç kavramlarını farklı disiplinlerden bilim insanları çok çeşitli yönleriyle incelemiştir. Yer değiştirme yöntemleri ve sebeplerindeki farklılıklar, kendi ülkesini terk ederek farklı bir ülkeye giden kişiler için sığınmacı, mülteci, göçmen, yerinden edilmiş kişi gibi farklı kavramların kullanılmasına neden olmaktadır.

Kendi içerisinde siyasal kriz yaşayan ülkelerin vatandaşlarının komşu ülkelere kaçması uluslararası hukuk dilinde "göçmen" kavramını ortaya çıkarmıştır. 1951 Mülteci Hukuki Durumunu konu alan Cenevre Sözleşmesi'ne göre mülteci; din, 1rk, politik düşünce, belirli bir gruba mensup olma durumu gibi sebeplerin sonucunda zülme uğrayacağını düşünerek, kendi ülkesini terk ederek başka bir ülkenin korumasından faydalanmak durumunda kalan kişidir (http://www.multeci.org.tr/wp-content/uploads/2016/12/1951-CenevreSozlesmesi-1.pdf/).

Sı ̆̆ınmacı ve mülteci kavramları uluslararası sözleşmeler ve devletlerin uygulamaları açısından fark1 algılanmaktadır (http://akademikperspektif.com/). Bir ülkede sığınma hakkı verilen kişi mülteci olarak tanımlanırken, Göç Terimleri Sözlügüne göre; "bir ülkede mülteci haklarından faydalanmak isteyen ve mültecilik statüsüne ilişkin yapılan başvuru sonucunu bekleyen kişi 'Sığınmacı', olarak ifade edilmektedir.

Türkiye'ye yönelen göç dalgalarının geçmişi eskilere dayanır. Son yıllarda ülkeye yönelen göç hareketleri Türkiye'yi aynı zamanda hem "göç alan" ülke, hem de "geçiş" ülkesi olma konumlarına taşımıştır (İçduygu, 2006:70). Suriyeliler, Türkiye'ye geldiklerinden bu yana hukuki anlamda net bir tanım içerisine konulamamıştır. Türkiye'nin yasal düzenlemelerinde net olarak yer bulunmayan uluslararası hukuk kavramlarının iç hukukumuzda netleştirilememesi Suriyelilerin farklı kavramlarla tanımlanmasına neden olmuştur. 2013 yılında yürürlüğe giren 6458 sayılı Yabancılar ve Uluslararası Koruma Kanunu ile birlikte Mülteci, Şartlı Mülteci, İkincil Koruma ve Geçici Koruma kavramları hukuk literatürüne girmiş ve bu kavramlar üzerinden Suriyeli mültecilerin hukuki statüsü belirlenmiştir (Uzun, 2015).

"Suriyeli mülteciler" meselesi geçmişten günümüze kadar devam eden göç dalgalarının en kapsamlısı olması bakımından çok farklı parametrelerle karşımıza çıkmaktadır. İçerisinde bulunduğumuz dönemi "göç çă̆ı" olarak yorumlamak doğru olacaktır. Türkiye'nin, 2011 yılına kadar devam eden süreçte genel bir göç politikası uyguladığını söylemek mümkündür. Arap Baharı süreciyle birlikte siyaset, diplomasi ve uluslararası ilişkilerin alanında köklü değişiklikler olmuştur. Türkiye coğrafi konumu itibariyle transit bir ülke olma özelliği taşımaktadır. 2011 yılından itibaren çatışma ortamından kaçarak Türkiye'ye sığınan yaklaşık 3,5 milyon Suriyeli mülteci geçici koruma altına alınmıştır. Türkiye'ye sığınan Suriyelilere yönelik "açık kapı" politikası yürütülmektedir. Türkiye tarafından geçici korunma altına alınan mülteci sayısı 2,8 milyondur. Kamplarda yaşayan mülteci sayısı 258 bin kişidir. Kentlerdeki mültecilerin oranı ise yüzde 92'yi bulmaktadır (Erdoğan, 2017:13).

Türkiye-Suriye ilişkilerinde gelişen bu hızlı değişimin sonucunda, Türkiye halkına ve ülkeye sığınan Suriyeli mültecilere yansıması oldukça önemlidir. Savaşın başlamasından itibaren geçen 7 yıllık süreçte mültecilerin yakın zamanda evlerine dönemeyecek olması ve çoğunluğun kent nüfusu haline dönüşmesi sonucu, konuk veya misafir gibi değil de kalıcı olarak görülmeye başlanmıştır. Bu bağlamda kent nüfusu haline dönüşen Suriyeli mültecilerin kültürel entegrasyon ve sosyal ilişki kurma konusunda sıkıntılar yaşadığ görülmektedir (Buz, 2008:14).

Türkiye vatandaşlarının Suriyeli mültecilere yönelik tutumlarını ötekileştirme pratiklerini doğru analiz etmek gerekmektedir. Öte kelimesinden türeyen "öteki" kavramı, "gündemde olandan veya göz önünde bulundurulandan geride kalanı" olarak tanımlanmaktadır. Tarih boyunca toplumların birlikte yaşama alışkanlıkları incelendiğinde; toplumsal hayatın akışı içerisinde bireylerin yaşadıkları toplumdan farklı bireylerle ya da yabancı olanlarla beraber yaşanmasının beraberinde getirdiğ en büyük problemlerden birinin "öteki”leştirme süreciyle ortaya çıkan algı olduğu görülmektedir. Gün geçtikçe Suriyelilere yönelik artan ayrımcı ve ötekileştirici söylemlerin artmış olduğu görülmektedir. Uluslararası göç kontrolsüz ve yoğun şekilde gerçekleştiğinde göç alan ülkelerde yabancı korkusu oluşmakta ve bu durum sosyo-kültürel yapıları olumsuz etkileyebilmektedir (Deniz, 2014:177). 


\subsection{Türkiye'deki Geçici Koruma Altındaki Suriyeliler}

Suriye'de yaşanan kriz, BM tarafindan son zamanların en büyük göç hareketi ve yurdundan edilme krizi olarak görülmektedir. Yaşanılan bu kriz sürecinin tam olarak sonlanmasının yıllar alacağı nerdeyse 10 yıllar bulabileceğine dair öngörüler bulunmaktadır (www.3rpsyriacrisis.org/). Bu nedenle, Suriye krizinin başladığı ilk süreçte geçici olarak görülen zorunlu göç hareketi zaman geçtikçe kalıcılığa doğru yön almaya başlamıştır.

Suriye'de yaşanan çatışma hali olarak Mart ayının ortalarında 2011 yılında, Arap Baharı adı ile başlayan protestolar sonucu başlamıştır. Nisan 2011 tarihi itibariyle ülke içerisinde ortaya çatışmalar sonucu ülke bir iç savaşa doğru sürüklenmiştir. Kısa sürede ülke geneline yayılan çatışma ortamı, ülkedeki gündelik hayatı yaşanamaz hale getirmiş ve Suriyeliler yaşadıkları tehdit ve güvensizlik sorunu nedeniyle ülkelerini terk etmek durumunda kalmışlardır. Devam eden iç savaş nedeniyle Suriye'de yoğun kitlesel iç ve dış göç yaşanmıştır. BM'nin resmi verilerine göre yaklaşık 6,5 milyon Suriyeli mülteci savaşın başladığı ilk süreçten itibaren ülkelerini terk ederek ülke dışında güvenli farklı bölgelere yerleşmiştir. Türkiye'nin bulunduğu jeopolitik konum itibari ile komşu ülke Suriye ile kültürel ve tarihi bağları bulunmaktadır.

Geride bıraktığımız 7 yıl içerisinde milyonlarca Suriyeli mülteciye ev sahipliği yapan Türkiye, mültecilere misafirperverlik gösteren ülkelerin başında yer almıştır. Türkiye topraklarına sığınan mülteciler başlanğıçta sınır bölgelerinde ve kamp alanlarında yaşamaya başlamışlar ve bölge illerinde ve kamplarda ikamet etmişlerdir. Suriye'deki çatışma sürecinin uzaması ve son bulmaması, artan göç hareketi sebebiyle kampların olanakları yetersizleşmiş ve temel ihtiyaçların karşılanmasında sorunlar yaşanır hale gelmiştir.

Kamplardan ayrılan birçok Suriyeli mülteci kentlerde bağımsız bir şekilde yaşamayı tercih etmiştir. Özellikle sınır illeri ve büyükşehirlere doğru hareket eden Suriyeliler, ev kiralarının uygun olduğu ve çalışabilecekleri sanayi bölgelerine yerleşmişlerdir. Bir süre sonra yerleştikleri kente akraba ve tanıdıklarının da gelmesi için vesile olmuşlardır (Güçtürk, 2014). Her geçen gün kentlerdeki nüfusu artan Suriyeliler neredeyse Türkiye'nin bütün vilayetlerine yerleşmeye başlamışlardır.

\subsection{Türkiye’deki Geçici Koruma Altındaki Suriyelilerin Statü- Sayı ve Bulguları}

İçişleri Bakanlığı Göç İdaresi Müdürlügü kayıtlarına göre, Türkiye'de 3 milyon 611 bin 834 Suriyeli yaşıyor. Suriyelilere ev sahiplği yapan şehirlerin arasında İstanbul birinci sırada yer almaktadır.

Tablo 1. Suriyelilerin Türkiye'deki Dağılımı

\begin{tabular}{|c|c|c|}
\hline ILLER & $\begin{array}{c}\text { KAYITLI SURIYELI } \\
\text { SAYISI }\end{array}$ & $\begin{array}{c}\text { NÜFUSA GÖRE } \\
\text { KARŞILAŞTIRMA YÜZDESİ }\end{array}$ \\
\hline İSTABUL & 558.437 & $\% 3.71$ \\
\hline ŞANLIURFA & 452.534 & $\% 22.23$ \\
\hline HATAY & 447.884 & $\% 27.82$ \\
\hline GAZIANTEP & 425.383 & $\% 21,02$ \\
\hline MERSIN & 206.241 & $\% 11,37$ \\
\hline ADANA & 235.434 & $\% 10,68$ \\
\hline BURSA & 167.615 & $\% 5,60$ \\
\hline KILIS & 114.788 & $\% 80,53$ \\
\hline İMIR & 142.819 & $\% 3,31$ \\
\hline KONYA & 106.641 & $\% 4,83$ \\
\hline
\end{tabular}

Kaynak: www.goc.gov.tr/ (Erişim Tarihi: 19.01.2019).

Yukarıdaki tabloda, Türkiye'de bulunan Suriyelilerin illere göre dağılımı vardır. Suriyelilerin bulunduğu yerleşim yerinden yedi tanesinde Geçici Barınma Merkezi bulunmaktadır. Kamplarda yaşamayı tercih etmeyen 
mülteciler kent halkıyla bir arada yaşamaktadır ve en fazla göç alan şehirlerin arasında İstanbul ilk sırada yer almaktadır.

Grafik 1. Geçici Koruma Altındaki Suriyeliler

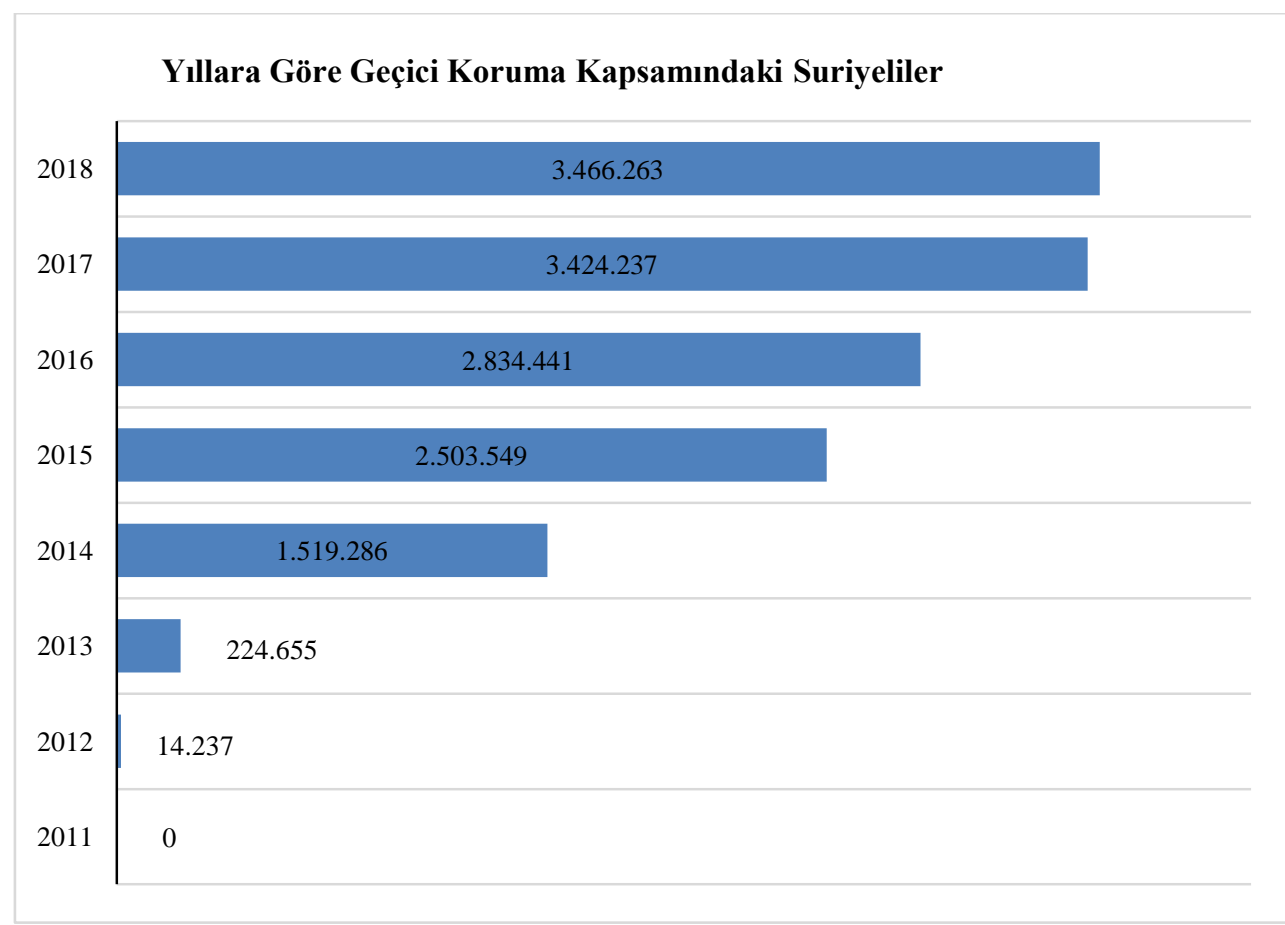

Kaynak: www.goc.gov.tr/ (Erişim Tarihi: 10.02.2018).

Yukarıdaki verilere göre, 2013 yılından sonra Türkiye’ye göç eden Suriyelerin saysının artmış olduğu görülmektedir.

Şekil 1. Geçici Koruma Altındaki Suriyelerin İlk 10 İle Dağı̆lımı

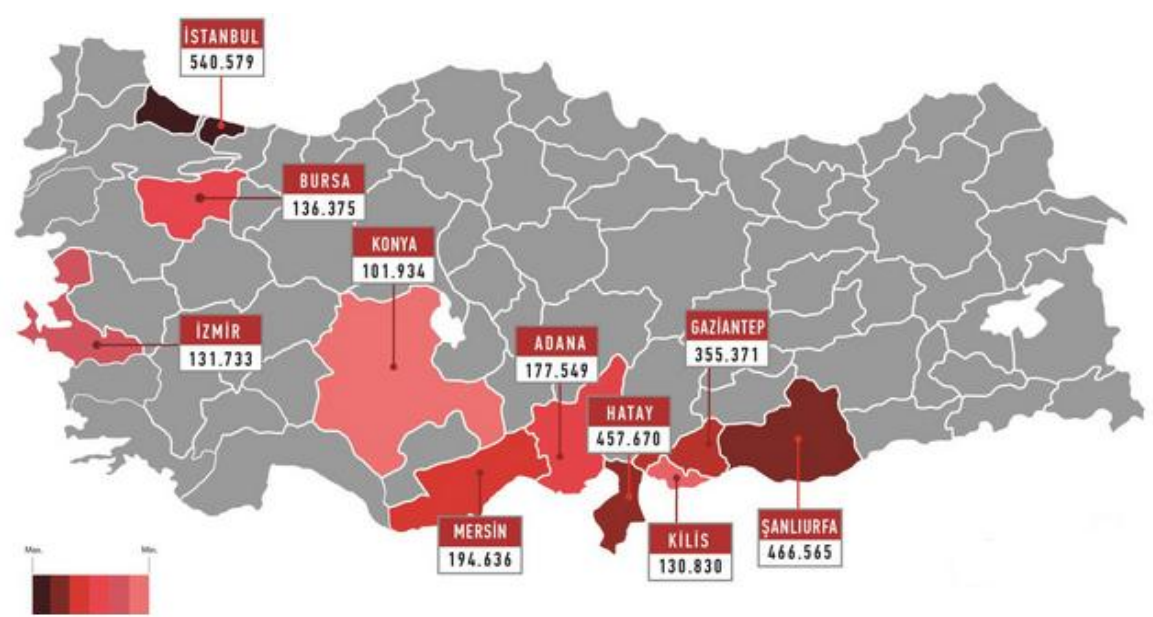

Kaynak: www.goc.gov.tr/ (E. T.: 10.02.2018).

Yukarıdaki haritada, geçici koruma altındaki Suriyelilerin illere göre dağılımı yer almaktadır. Haritada yer alan illerden; İstanbul, Şanlıurfa ve Gaziantep en fazla Suriyeli mülteciye ev sahipliği yapmaktadır. 
Tablo 2. Yaş ve Cinsiyet Dağılımına Göre Suriyeli Verileri

\begin{tabular}{|c|c|c|c|}
\hline YASŞ & ERKEK & KADIN & TOPLAM \\
\hline TOPLAM & 1.888 .633 & 1.597 .011 & 3.485 .644 \\
\hline $0-4$ & 233.484 & 217.883 & 451.367 \\
\hline $5-9$ & 244.922 & 229.624 & 474.546 \\
\hline $10-14$ & 194.531 & 179.707 & 374.238 \\
\hline $15-18$ & 156.106 & 127.653 & 283.759 \\
\hline $19-24$ & 310.465 & 221.891 & 532.356 \\
\hline $25-29$ & 196.340 & 143.245 & 339.585 \\
\hline $30-34$ & 164.719 & 123.430 & 288.149 \\
\hline $35-39$ & 116.143 & 91.891 & 208.034 \\
\hline $40-44$ & 78.123 & 70.424 & 148.547 \\
\hline $45-49$ & 58.894 & 54.753 & 113.647 \\
\hline $50-54$ & 47.611 & 45.450 & 93.061 \\
\hline $55-59$ & 31.810 & 31.755 & 63.565 \\
\hline $60-64$ & 22.790 & 23.305 & 46.095 \\
\hline $65-69$ & 14.842 & 14.971 & 29.813 \\
\hline $70-74$ & 8.217 & 9.101 & 17.318 \\
\hline $80-84$ & 2.693 & 3.441 & 6.134 \\
\hline $85-89$ & 1.410 & 1.763 & 3.173 \\
\hline $90+$ & 743 & 959 & 1.702 \\
\hline
\end{tabular}

Kaynak: İçişleri Bakanlığı Göç İdaresi Genel Müdürlüğü (Erişim Tarihi: 01.02.2018).

Yukarıdaki tabloda, Suriyeli mültecilerin yaş ve cinsiyet dağılım oranları yer almaktadır. Çocuk ve genç nüfus oranın yüksek olması entagrasyon sürecini hızlandırmaktadır.

Grafik 2. Suriyeli Çocukların Yıllara Göre Okullaşma Sayısı

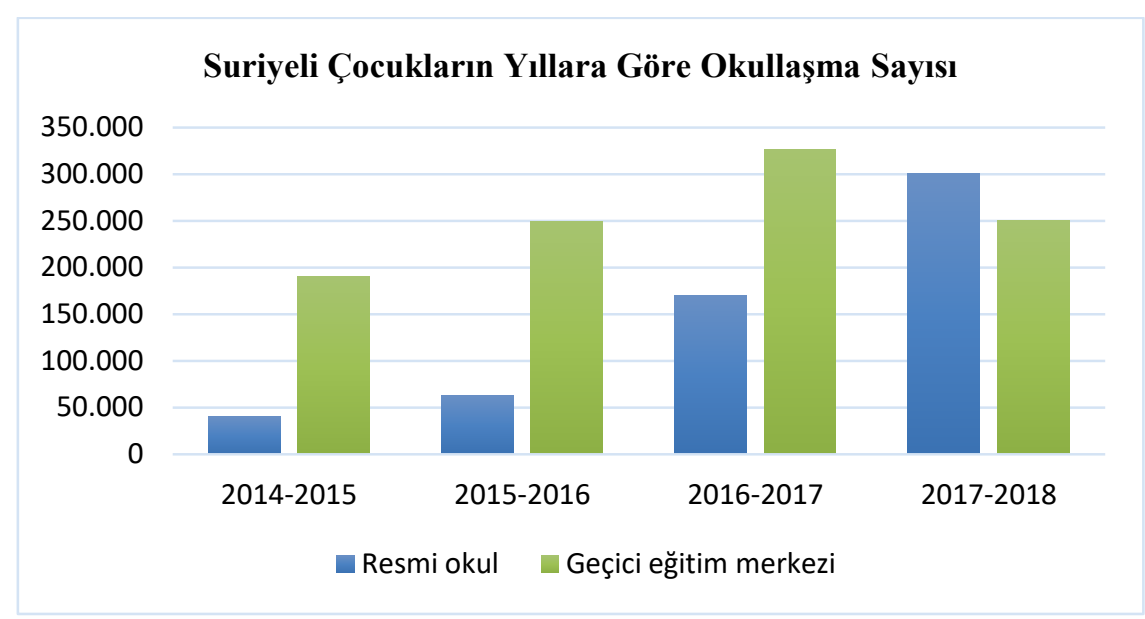

Kaynak: http://www.setav.org/ (E. T.: 10.02.2018). 
Yukarıdaki grafikte, Suriyeli çocukların yıllara göre eğitim hayatına devam edebilme oranları verilmiştir. Türkiye'ye göç ettikleri ilk yıllarda geçici eğitim merkezlerinde eğitim gören çocukların, ilerleyen yıllarda resmi okullarda eğitim görme oranın artmış olduğu görülmektedir.

Etnik özelliklerde değissim: Suriye'de savaşın başladığı ilk süreçte Türkiye'ye sığınanların büyük bir çoğunluğunu Sünni Araplar oluşturmaktaydı. 2014 yılı itibariyle Suriye'de çatışma ortamının artaması ve DAEŞ etkisi nedeniyle Türkiye'ye sığınanların sayısı artmış ve etnik-dini yapısında önemli ölçüde değişiklik söz konusu olmuştur. Ezidiler, Ermeniler, Kürtler gibi pek çok "Arap Sünni” olmayan Suriyeliler, Türkiye sinır kapılarından giriş yapması ve Türkiye'nin insanlık adına kapılarını sonuna kadar açması mevcut tedirginliği azaltmıştır.

Uluslararası kamuoyunun Suriyelilere duyarsızlı̆̆ı: Gelişmiş ülkeler savaşın başladığ 2011 y1lından günümüze kadar yaşanılan bu insani drama karşı kayıtsız ve yetersiz kalmıştır. Savaşın ilk yıllarında Batı ülkelerince toplam Suriyelilerin yüzde 2-3'ü alınmış veya alınmaları taahhüt edilmiştir. 2019 yılına kadar geçen süreçte Avrupa ülkeleri yaklaşık bir milyon Suriyeli kabul etmiştir. Bu ülkeler mali destek ve sığınmacınlara ev sahipliği yapma konusunda başarısız olmuştur.

Suriyeliler ve İşsizlik: Türkiye 7 yılda yaklaşık 3,5 milyonun üzerindeki Suriyeliye ev sahipliği yapmaktadır. $\mathrm{Bu}$ kapsamlı göç hareketinin mevcut iş piyasında yaratmış olduğu değişiklik kent halkını hızursuz etmektedir. Türkiye İşveren Sendikaları Konfederasyonu (TISSK) ve Hacettepe Üniversitesi ortaklığı ile 2016 yılında yapılan araştırma verilerine göre; Türkiye'de 300 bin Suriyeli çalışmaktadır. İLO tarafından "Suriyeli işçi, işveren ve girişimcilerin sorunlara" yönelik gerçekleştirilen çalıştay sonuçlarına bakıldığında, Suriyelilerin istihdam edildiği alanların; çoğunlukla mevsimlik tarım, inşaat, imalat ve tekstil sektörleri olduğu görülmektedir. T. C. Ekonomi Bakanlığı'nın açılamasına göre, 2015 Haziran ayından itibaren Türkiye'de 2.827 Suriyeli firma sayısı bulunmaktadır. Türkiye Odalar ve Borsalar Birliği'nin (TOBB) kayıtlarına göre Suriyeliler tarafından kurulan şirket sayısı 2010'da 30, 2015'te 1599'a ulaşmıştır ve 2016'nın ilk yarısına gelindiğindeyse 589 firmanın açıldığı kayıtlara geçmiştir. Aile, Çalışma ve Sosyal Hizmetler Bakanlığının 15 Kasım 2018'de yapmış olduğu açıklamaya göre Türkiye'de çalışma izni verilen Suriyeli sayısı yalnızca 32 bin 199 kişidir (www.ilo.org/). İşveren açısından ucuza çalışmaya hazır insanları istihdam etmek avantaj sağlamaktadır. İş gücü arzının artmasıyla rekabetin de artması, kayıt dışı çalışan işçi sayısının fazla olması ve ucuz iş gücünün piyasadaki rekabeti olumsuz yönde etkilemesi toplumun kaygılanmasına sebep olmaktadır. Suriye'den gelen sığınmacıların yarattığı yeni ekonomi ve TÜIKK verileri sonucuna göre işsizlik rakamı azalmış ve istihdam kapasitesinin artmış olduğu görülmektedir.

\subsection{Alan Çalışması: Esenyurt}

Şekil 2. Esenyurt/Kıraç Bölgesi Haritası

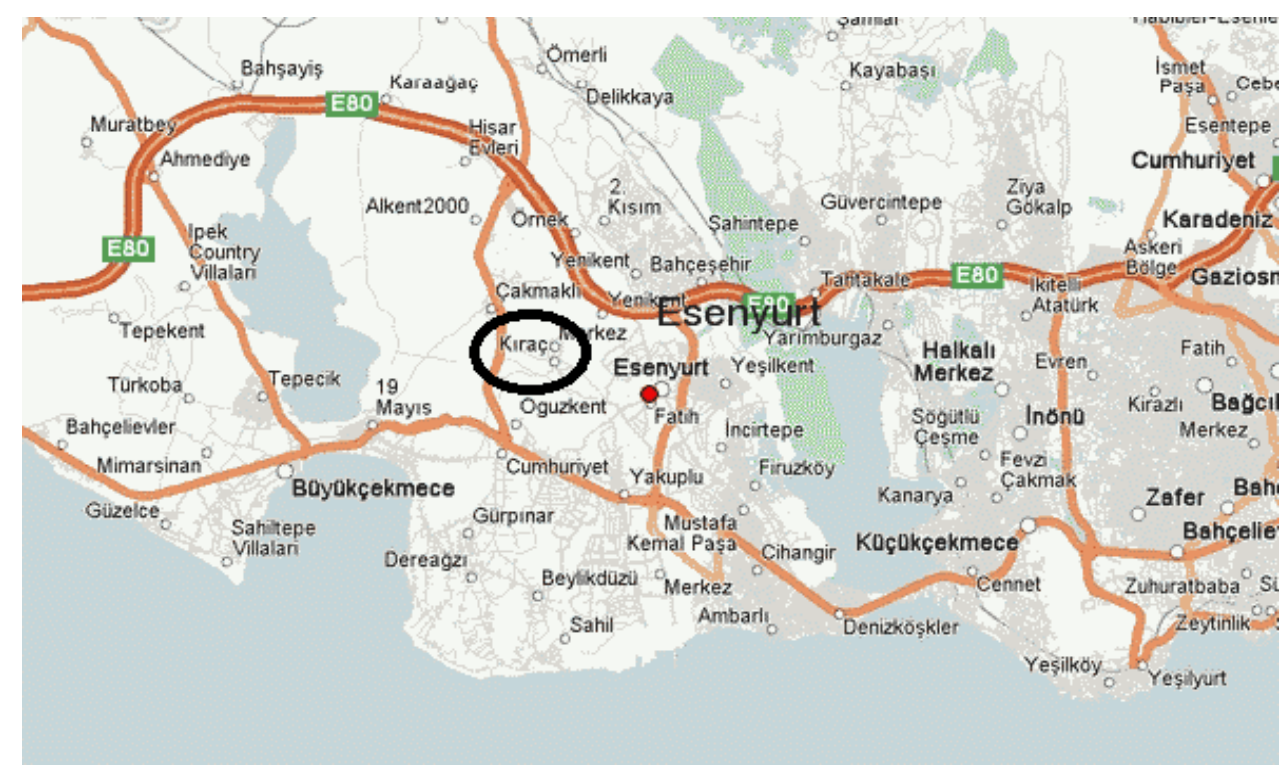

Kaynak: İstanbul Haritası. 


\subsubsection{Araştırmanın Konusu}

Bu çalışmada 2011 yılından itibaren ülkelerinde başlayan çatışma ortamının giderek artması sebebiyle geçici koruma altınaaa alınarak Türkiye sınırlarına sığınan Suriyelilerin, Türkiye'deki toplumsal kabul ve uyumlarıyla göçmen deneyimleri ele alınmıştır. Bu konu Esenyurt bölgesinde yapılan kapsamlı bir araştırma ile aktarılmak istenmiştir.

\subsubsection{Araştırmanın Amacı}

Çalışmada Suriye'de çıkan iç savaş nedeniyle göç eden Suriyelilerin kentlere uyum sürecindeki olumlu ve olumsuz etkisinin İstanbul'un Esenyurt bölgesi özeliyle değerlendirilmesi amaçlanmıştır. Ayrıca bu çalışmayla sosyo-ekonomik etkileşimin medyadaki yansıması incelenerek haber içeriklerinin kamuoyuna nasıl aktarıldığı incelenmektedir.

\subsubsection{Araştırmanın Önemi}

Ülkemizin en önemli konularından biri olan sığınmacılar olgusunun özellikle görünmeyen kentsel boyutlarını anlamaya çalışmak ve sonuçta çözüm önerileri sunmak için bir fikir ortamı oluşmasına zemin hazırlamakla farkındalığı artırmak bu çalışmanın önemini tanımlamaktadır.

\subsubsection{Kapsam ve Sinırlılıkları}

Araştırma Suriye'deki iç savaştan kaçarak gelen ve İstanbul il sınırları içerisindeki Esenyurt ilçesinde bir arada yaşayan Suriyeli mülteciler ve kent halkı ile sınırlandırılmıştır. Esenyurt bölgesinin kentsel özellikleri, sosyokültürel yapısı, eğitim düzeyi, bölgeye gelen Suriyelilerin burayı ne ölçüde etkiledikleri üzerinde durulmuştur. Kentsel alana gelen Suriyelilerin kentlileşmesi için yalnızca buraya gelip yerleşmesi, çalışması yeterli değildir. $\mathrm{Bu}$ kişilerin aynı zamanda kentsel kalıp davranışlarını, sosyo-kültürel özelliklerini benimseyip sindirmesi gereklidir.

Çok sayıda Suriyeli mültecinin misafirlikten kalıcı duruma geçmesiyle birçok sorunla karşı karşıya kalınmıştır. Çalışmada Suriyeliler hakkında çıkan haberlerin toplum üzerindeki etkisi de göz önünde bulundurularak karşı1ıklı uyum süresi ele alınmıştır. Araştırma için bölgede yaşayan 6 - 55 yaş aralığındaki 30 Suriyeli aile ve Esenyurt halkından yaklaşık 100 kişi ile Suriyeliler ve yerel halk ile derinlemesine mülakatlar yapılarak veriler toplanmıştır. Soru - cevap şeklinde yapılan konuşmalarla konu detaylandırılmaya çalışılmıştır.

\subsubsection{Yöntem}

\subsubsection{Araştırma Çerçevesinde Yapılan Çalışmalar}

Derinlemesine mülakatlar: İstanbul'un Esenyurt ilçesinde yüz yüze görüşme yöntemiyle tabakalaşma dinamikleri açısından Suriyeliler ve yerel halk ile derinlemesine görüşmeler yapılarak fotograf ve video kaydı alınmıştır. Bu bilgiler yüz yüze yapılan soru-cevap tekniğiyle toplanmıştır. Veriler yapılan ropörtaj, kamera ve ses kayıtlarının yazıya dökülmüş şeklidir. Ekim (2017) - Ocak (2018) tarihleri arasında röportajlar gerçekleştirilmiştir. Bölgedeki Suriyeliler ve yerel halk ile yapılan mülakatlarda karşılıklı etkileşim temelindeki sonuçlar alınmıştır.

Medya Analizi: Çeşitli medya kuruluşlarının web üzerinden paylaştıkları haber metinleri Van Dijk'ın eleştirel söylem analizine göre incelenmiştir. Esenyurt"ta yaşayan Suriyeliler hakkında medyada yer alan (47) haber içeriği incelenmiştir. Suriye"de krizin başladığg 2011 yılından günümüze kadar medyada olumlu (21), olumsuz (17) ve yansız (9) olarak yer alan haber metni analiz edilmiştir.

\subsubsection{Uygulama}

\subsubsection{Mülakatlar}

Çalışmanın katılımcıları Esenyurt'ta yaşayan her yaştan Suriyeli mülteciler ve yerel halk olmak üzere özellikle enformel sektörde çalışan çocuk, kadın ve erkek iş gücü görüşlerine basit tesadüfi örnekleme yöntemi ile başvurulmuştur. Farklı söylemlerin etkisini incelemek amacıyla yaş, medeni durum, meslek gibi farklı kategorilerdeki katılımcılarla görüşmeler gerçekleştirilmiştir. Katılımcı sayısı söylem kalıpları birbirini tekrarlamaya başladığında veri toplama işlemine son verilmiştir.

Görüşmeler Esenyurt ilçesindeki mahallelerde gerçekleştirilmiştir. Yapılan görüşmelerin süresi 10 - 30 dakika arasında değişmektedir. Görüşmelerin temalarını Esenyurt'taki Suriyelilerin, Türkiye'ye geliş nedenleri, yaşam 
koşulları, iş ve aile hayatları, ülkemiz hakkındaki görüşleri, yerel halkın Suriyeliler hakkındaki düşüncelerini oluşturmaktadır.

Yürütülen bu çalışma etnik, dilsel, kültürel, siyasi gibi başlıklarla ilişkilendirilerek yürütülmüştür. Görüşmeler sırasında katılımcılara hiçbir şekilde müdahale edilmemiş olup detaylar sonrasında açıklanmaya çalışılmıştır. Görüşmelerde belirlenen ana temalar aşağıdaki gibi sıralanabilir.

\section{Mültecilere sorulan sorular:}

- Tükiye'ye geliş ve burada kalış süreniz nasıl gelişti?

- Burada yaşam koşullarınız nasıll?

- Türkiye'de yaşadığınız sıkıntılar nelerdir?

- Çalışma koşullarından memnun musunuz?

- Suriye'deki akrabalarınızla görüşebiliyor musunuz?

- Ülkemizdeki insanlarla olan ilişkileriniz nasıl?

- Geri dönmeyi düşünüyor musunuz?

- Gelecekten beklentileriniz nelerdir?

\section{Yerel halka sorulan sorular:}

- Suriyelilerle bir arada yaşamaktan memnun musunuz?

- Esenyurt’ta geçici koruma altında yaşayan mültecilerle ilgili temel sıkıntılarınız nelerdir?

- Suriyelileri tehdit ve risk unsuru olarak görüyor musunuz?

Sorulacak olan soruların bazılarının önceden belirlenmesi röportajların daha planlı şekilde yapılmasını sağlamıştır. Başlangıçta sorulmuş olan soruya göre de görüşmeler şekil almıştır.

\subsubsection{1. İçerik İncelemesi}

$\mathrm{Bu}$ çalışmada ses kayıt ve video tekniği ile yapılan mülakatların içeriği deşifre edilmişitir. Suriyelilerin ve yerel halkın açıklamalarının dayandığı temel noktalar, kendilerini nasıl hissettikleri incelenmiştir. Sonuçta ortaya çıkan ana düşünceler aşağıdaki gibi olmuştur.

\section{Alıntı:}

"Çok şeyler gördük, bomba düştü üzerimize, evimiz yıkıldı",

Katılımcılar, ülkelerinde savaşın çıkmasıyla birlikte, yaşadıkları yerlerin yerle bir edildiğini ve yakınlarının ölümlerine tanıklık ettiğini söylemişlerdir. Hayatta kalmak ve çocukları için bu yolculuğa mecburen çıktıklarını dile getirmişlerdir.

Katılımcı 1 - Suriye'de Halep'te yaşıyorduk. Biz okuldayken bomba düştü üzerimize, bacağım yaralandı. Çok şeyler gördük. Evimiz yıkıldı, bakkalımız vardı yıkıldı. Arkadaşlarımdan ölen çok oldu. 2013 yılında kaçak bir şekilde geldik buraya. Suyun içine girdik. 4 km kadar yürüdük. Buraya geldiğimizde her şey kötüydü. Sonra güzel bir dünya gördük. Bir arada olduk. Geldiğimde 8 yaşındaydım şimdi 12 yaşındayım. Buraya gelir gelmez Türkçe'yi öğrendim. Çalışmaya başladım. Sabah 08.30 'dan gece 01.00 'e kadar oto sanayide çalışıyorum. Türkiye'de her şeyi sevdim. Bütün milletleri bütün dünyayı seviyorum.

Katılımcı 2 - Biz Halep'te yaşıyorduk. Hiçbir sorunumuz yoktu sonra savaş oldu. Suriye'den çıkmayı hiç düşünmüyorduk. Sonra savaşın ortasında kaldık üzerimize bomba attılar. Akrabalarımız öldü, evimiz yıkıldı. Suriye askerleri geldi bize çok kötü davrandı ve biz mecburen Suriye'den çıkmak zorunda kaldık. Orada hala akrabalarımız var. Biz çalışıp para biriktirip Suriye'ye gitmek istiyoruz, akraba, komşu ve tanığımız aileler kim varsa buraya getirmek istiyoruz.

Katılımcı 3 - Kışın geldik, kar vardı, yağmur vardı. Çok zordu. Büyük kızım hastaydı, Onu doktora götürdük. Elimizde kimliği olmadığı için tedavi edemeyeceklerini söylediler, bizi göndermek istediler. Kız ölüyordu elimizde, çok zordu gelişimiz. Çocuklar hastalandı, biz hastalandık. 


\section{Alıntı:}

\section{"Rızkımızın peşinden geldik"}

Enformel sektörde çalışan katılımcılar, Türkiye'de çalışma koşullarına dair görüşlerini belirtmiştir. Görüşme yaptığımız kişilerin bir kısmı Türkiye'de çalışma koşullarının yetersiz olduğunu ve geçinemediklerini dile getirirken bir kısmı ise memnun olduğunu dile getirmiş̧tir.

Katılımcı 4 - 30 yaşındayım. Tekstil atölyesinde ortacılık yapıyorum. Aylık 600 TL ücret alıyorum. Suriye'de çalışmıyordum. Türkiye'de yaşayabilmek zor bir şey. Ev kirası pahalı, ev sahibi sürekli bizi tehdit ediyor kirayı artıyor. Çocuklarımı okula gönderemiyorum. 4 çocuğum var çocuklarım çalışarak bize katkıda bulunuyor. Burada ne iş var ne de okul.

\section{"Katılımcı 5 - "Çalışarak özgür olduğumu hissediyorum"}

Suriye'de çalışmıyordum. Türkiye'de hayat koşulları zor. Geldiğimin ikinci günü iş aramaya çıktım. Hemen iş buldum. İlk önce pastanede çalıştım, sonra çaycılık yaptım. Kimseye de muhtaç olmadık. Eşim de iş buldu. Fatura, kira ve çocukların ders parasını ödemek gibi kaygılarımız oluştu. Şu an bunların hepsini düşünmek zorundayım. Çocuklarımın daha iyi yaşabilmeleri için daha çok çalışmak zorundayım. Kendi ayaklarımın üzerinde durabiliyorum ve kendimi çalışarak özgür hissediyorum. Çok şükür çocuklarımı okula yerleştirdim. Araba bile aldık. Her şey iyiye gidiyor. Türkiye'de yaşamaktan memnunum ve artık Suriye'ye dönmeyi düşünmüyorum.

Görüşlerine yer verdiğimiz 2 kadın katılımcı daha önce Suriye'de çalışmadıklarını, Türkiye'de geçim sıkıntısı yaşadıkları için aile bütçesine katkı sağlamak amacıyla çalışmak zorunda kaldıklarını belirtmişlerdir.

\section{Katılımcı 6 - "Çöpün yanından bile geçmezdik Şimdi rızkımız çöpten topluyoruz"}

Biz Şam'da yaşıyorduk işimiz çok zordu. Rızkımın peşinden geldik, ne iş olsa onu yapıyoruz. Sadece ben çalışıyorum, karton topluyorum. 3 çocuğum, annem ve karımla birlikte 6 kişiyiz. Şam'dayken çöpün yanından bile geçmezdik ama şimdi rızkımızı çöpten topluyoruz. Üzerimizdeki elbise çöpten,yemeğimizi çöpten topluyoruz. Bizim için çok zor ama başımı önüme eğip allyorum. Ben istiyorum ki iyi bir işim olsun, çocuklarım bir şeye muhtaç olmasın. Okula gidebilsin, cahil kalmasın. Dil öğrensin, her şey öğrensin, alim olsunlar. Hayatları güzel olsun.

\section{Alıntı}

\section{"Okula gitmek istiyorum ama gidemem"}

Çocuk katılımcılardan birçoğu ülkelerinde okula gittiklerini, ancak ülkemize göç ettiklerinde özellikle maddi sorunlardan dolayı okumaya devam edemediklerini söylemişlerdir. Okumak istediklerini dile getirmişlerdir.

Aşağıda sunulan 3 alıntı buna örnek olarak verilebilir:

Katılımcı $7-3$ senedir buradayım. Savaş olunca buraya geldik. Okula gitmek istiyorum ama gidemem, çünkü savaş var ve paramız yok. Bunun için çalışmak zorundayız. Suriye'de savaş altında 1 sene bombalar altında kaldık. O yüzden buraya geldik. Ailemizde başka çalışacak kimse yok. Tek ben çalışıyorum ve okula gidemem.

Katılımcı 8 - 12 yaşındayım, Halep’ten geliyorum. Burada selpak satıyorum. İnsanlar iyi davranıyor ama hepsi değil. Ülkemde okula gidiyordum burada da okula gitmek istiyorum.

Katılımcı 9 - Şam'da hukuk öğrencisiydim. Burada üniversiteye devam etmek istedim ama kimliğim olmadığı için devam edemedim. Tek hayalim iyi bir gelecek. Üniversite okumak istiyorum. Fazla bir şey istemiyorum ne villa ne hazine istemiyorum sadece okumak istiyorum.

Her 3 alıntı da farklı kişiler ile yapılmış olan görüşmelerdir. Kendilerini tanıtmayla başlayan konuşmalar çocukların sıkıntı ve eğitim konusundaki düşüncelerini açıklamayla devam etmiştir. 


\section{Alıntı:}

\section{"Kimliklerimiz olmadığı için sıkıntı çekiyoruz"}

Katılımcıların çoğunlukla dile getirdiği açıklamalardan biri de kimliklerinin olmamasından kaynaklanan sorunlardır.

Katılımc 10 -Kimliğim yok. Hastaneye gideyim istiyorum ama kimliğim yok diye hastaneye almıyorlar. Pasaportumuz da savaş sırasında kayboldu. Biz hastaneye gittiğimizde bizi tedavi etmiyorlar.

Katılımcı 11 - Oğlum İbrahim, hasta kalbi delik. Hastaneye götürdük, ameliyat yapamayız dediler, ilaç verdiler. Kimliğimiz olmadığı için ilaçları alamıyoruz, çoğu zaman komşularımızdan yardım istiyoruz.

Katılımcıların birçoğu yukarıdaki örnek alıntılardan da anlaşılacağı gibi kimliklerinin olmamasından dolayı yaşadıkları sıkıntıları dile getirmişlerdir. Bunları eğitim ve özellikle sağlık alanıyla temellendirmişlerdir. Çocuklarının kimliklerinin olmamasından dolayı okullara kayıt ettiremediklerini, hastaneye gittikleri zaman da kimlik, pasaport gibi belgelerinin olmamasından dolayı istedikleri gibi tedavi olamadıklarını belirtmişlerdir.

\section{Alıntı:}

\section{"Dil sıkıntısı yaşıyoruz"}

Katılımcı 12 - Türkiye'de dil sorunu var. Avrupa'da dil öğretiyorlar veya dil öğrenmeye destek veriyorlar. Ama burada kendi kendimize Türkçe öğrenmeye çalışıyoruz.

Katılımcı 13 - 2 yıl önce Şam'dan buraya geldim, orada üniversiteye gidiyordum. Suriye'de durum çok zor o nedenle buraya geldik ama buraya geldiğimden beri durumum hiç iyi değil, okumak için para lazım. Hala iş bulamadım, üstelik dil sorunu var ve bu konuyla alakalı olarak hükumet bize yardım etmiyor.

$\mathrm{Bu}$ örnek alıntılarda ise en önemli sorunlardan biri olan dil sorunu ön plana çıkmaktadır. Görüşme yapılan katılımcıların bahsetmiş olduğu ana sorunlardan birisi olan dil sorunu onların topluma olan uyum sürecini, sosyal yaşamlarını da etkilemektedir. Katılımcılar bu sorundan genellikle görüşmelerin ortasına doğru bahsetmektedir. 13. katılımcı kendisini iş bulmak isteyen ancak dil sorunundan dolayı bunu yapamayan biri olarak konumlandırmıştır. Bir önceki alıntıda ise yine dil konusundaki eksikliklerden dolayı olan sıkıntılar dile getirilmiştir. Buradan da dil sorunun çözülmesinin Suriyeliler için ne kadar önemli olduğu gerçeğini çıkarabiliriz.

\section{Alıntı:}

\section{"Komşularımız çok iyi, kibar insanlar"}

Görüşleri alınan katılımcıların bazıları, Türkiye'de yerel halka yaşamaktan memnun olduklarını söylemişlerdir. Bir kısmı ise yerel halk tarafından hiç iyi muamele görmediklerini ve öteki olarak görüldüklerlini dile getirmiştir.

Katılımcı 13 - Buradakiler bazen iyi davranıyor bazen kötü. Git buradan diye kovuyorlar bizi.

Katılımcı 14 - Burada insanların iyisi de var kötüsü de var. Türkler, Arapların yaşam tarzlarına bakarak çok zenginsiniz diyorlar. Araplar çalışıyor, yemeyi, içmeyi, gezmeyi çok seviyorlar. Beni görüyorlar kimse benim Suriyeli olduğumu anlamıyor. Komşularım, herkes benden çok memnun ben de onlardan memnunum.

Katılımcı 15 - Biz burada kendimizi ülkemizde gibi hissediyoruz, burada mülteci değiliz, biz misafir gibi hissediyoruz. Komşularımız çok iyi, kibar insanlar. Allah herkesten razı olsun. 


\section{Alıntı:}

\section{"Allah savaşın üzerine bir su döksün bu savaş bitsin bizde evimize dönelim"}

Katılımcıların neredeyse hepsi savaş biter bitmez ülkelerine dönmek istediklerini belirtmiştir. Burada kendilerini ne kadar güvende ve iyi hissetseler bile hiçbir yerin kendi toprakları gibi olamayacağını söylemişlerdir.

Katılımcı 16 - Evimizi ölülerimizi ülkemizde bıraktık. Dönmek istiyoruz orası bizim vatanımız. Bize burada ne kadar iyi davransalar da evimiz gibi olmuyor. Evimiz yıkıldı hiçbir şey kalmadı, her şey yerle bir oldu. Allah savaşın üzerine bir su döksün bize sabır versin ki bu savaş bitsin bizde evimize dönelim. Ülkemizin olmasını istiyoruz, dönüp gitmek istiyoruz. Çocuklarımız ve herkes için istiyoruz.

Katılımc 17 - Nereye gidersem gideyim hiçbir şey benim topraklarımdan daha güzel olamaz. Suriye'de savaştan önce kardeşlerimle bir aradaydık. Savaştan sonra hepsi bir yere dağıldı. Küçük kardeşim Irak'a gitti, büyügü Danimarka'da. Bir kız kardeşim Almanya, diğeri İzmir'de. Biz istiyoruz ki hepimiz birlikte olalım, görüşebilelim ama bu çok zor. Keşke birbirimizi görsek. İnşallah hepimiz döneriz.

\section{Alıntı:}

\section{"Suriyelilerden memnun değiliz"}

Yerel halk ile yapılan görüşmelerin sonucunda ise ortaya çıkan en büyük düşünce onlardan memnun olunmadığı gerçeğidir.

Katılımcı 18 - Suriyelilerle ülkemde yaşamaktan memnun değilim. Başka bir ülkeye gitmiş olsalar o ülkenin onları kabul etmesi imkansız. Biz kabul ettik. Biz aynı duruma düşsek kimse kabul etmezdi. Biz neden kabul ettik bilemiyorum.

\section{Alıntı:}

\section{"Suriyeliler ile bir arada yaşamaktan memnun değiliz"}

Katılımcı 19 - Suriyelilerden memnun olmamamızın en önemli nedeni istediğimiz gibi bir iş bulamamamız. Bir fabrikaya gidip çalışmak istediğinde, işveren sana vereceği sigorta, maaş yerine sigortasız ve düşük ücretle çalışacak Suriyeliyi tercih ediyor. Öncelik onlara tanındığı için haliyle biz işsiz kalıyoruz. Bir ev sahibi400 450 TL karşılığında bana verebileceği evi Suriyeliye daha yüksek fiyatla vermeyi tercih ediyor. Gelirimiz belli, asgari ücret alıyoruz. Kira fiyatları artıyor, çocuk okutuyorsun bir de evde çalışan tek kişi olunca her şey daha da zorlaşıyor.

\section{Alıntı:}

\section{"Onlart burada istemiyoruz"}

Katılımeı 20 - Onları burada istemiyoruz çünkü iyi niyetimizi suiistimal ediyorlar. Sayıları oldukça arttı ve konuştuklarından hiçbir şey anlamıyoruz. Yoldan geçerken benim gibi genç kızlara laf atıyorlar. Bu bizi çok rahatsiz ediyor.

Yukarıdaki 3 alıntıda görüldüğü gibi yapılan görüşmelerin genelinde Suriyelilerle bir arada yaşamaya dair memnuniyetsizlik sonucu çıkmaktadır. Yerel halk yaşadığı sorunlardan bahsedip Suriyelileri neden tam olarak benimsemedikleri üzerinde durmuşlardır.

\subsubsection{Medyada Esenyurt}

Gazete, dergi, televizyon ve sosyal medya gibi yazılı ve görsel medya üzerinden yapılan değerlendirmelerde sığınmacıların yayımlanan haberlerde nasıl ifade edildiği kadar nasıl ifade edilmediği de önem teşkil etmektedir. Çalışma kapsamında incelenmiş olan haber metinlerinin bir kısmında Suriyeli sığınmacılardan olumlu şekilde bahsedilip korunması gerektiği belirtilirken, bir kısmında ise sığınmacıların olumsuz özelliği üzerinde durduğu görülmüştür. Bu incelemede, haber metinleri üzerinde yorum yapmaksızın tarafsız gözle bu konu yansıtılmaya çalışmıştır. 
Esenyurt'taki Suriyeli mültecilere yönelik çıkan haber metinlerinin içerik analizini aşağıdaki gibi sınıflandırmak mümkün olmuştur:

Olumlu Metinler (21 haber metni üzerinden) :

- Sığınmacıları ülkemize olan katkılarını arttıran,

- Olumsuz tutumları kinayan,

- Haklarını korumaya yönelik görüşlere yer veren,

- Sığınmacıları yaşadığı zorluklardan bahseden,

- Sığınmacılara yönelik düşmanca ve ırkçı söylemleri kınayan metinlerdir.

\section{Olumsuz Metinler (17 haber metni üzerinden) :}

- Siğınmacılar hakkında olumsuz tanımlar kullanan,

- Sığınmacıların varlığına karşı, dışlayıcı ve düşmanca söylem kullanan,

- Sığınmacıları ekonomik külfet, işsizlik ya da kira artışının nedeni olarak yorumlayan,

- Sığınmacıları ülkemizi kaosa sürükleyen olarak tanımlayan metinlerdir.

\section{Yansız Metinler (9 haber metni üzerinden) :}

- Sığınmacılarla alakalı gerçekleri ve verileri yorumsuz şekilde aktaran,

- Olumlu ya da olumsuz bir dile yer vermeyen,

- Sorunun her 2 tarafına eşit yer veren metinlerdir.

Şekil 1. Esenyurt’ta Suriyeli Fidyeciler Suriyeli Genci Kaçırdı (Milliyet Gazetesi)

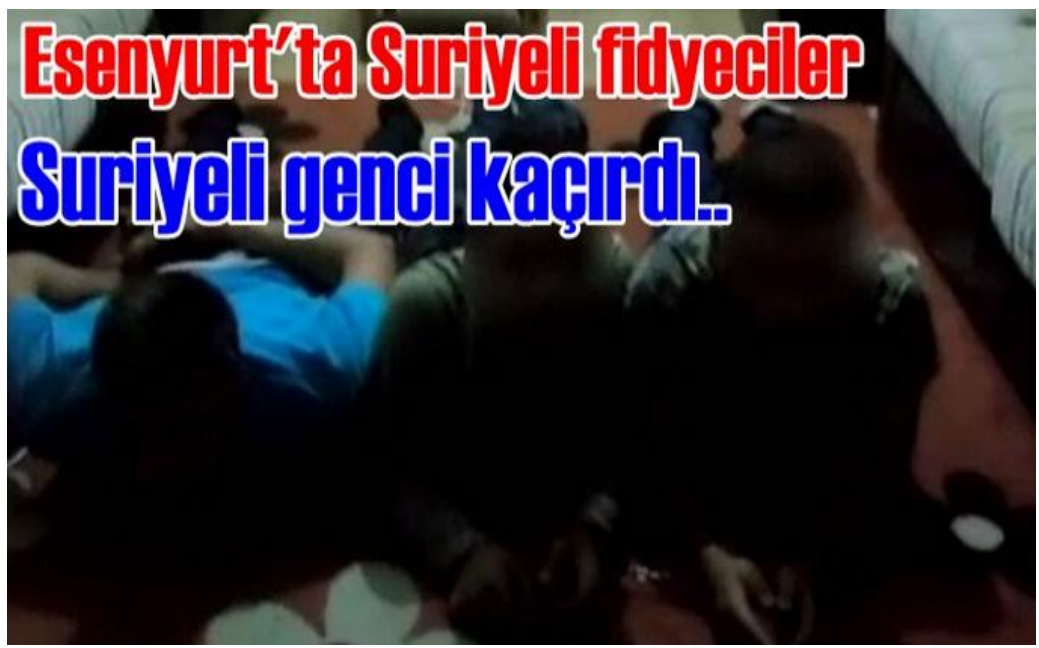

Kaynak: ( www.milliyet.com.tr, 2017/, E. T.: 19.02.2018)

Esenyurt'ta market işleten 2 soydaşını, yanlarına gönderdikleri yardıma muhtaç görüntüsü verilen bebekli bir kadınla tuzağa düşürerek kaçıran ve kaçırdıkları şahısların ailelerinden kişi başı 15 'er bin lira fidye isteyen çoğu Suriye uyruklu şahıslardan oluşan bir çete, kaçırdıkları rehinelere hortum ve elektrikle yaptıkları işkenceleri ailelerine görüntülü aramayla izletip para istedi. Suriyeli çetenin elinde bulunan 2 rehineden birisi kendi imkânlarıyla çetenin elinden kaçıp kurtulurken, bir diğeri ise polis operasyonuyla kurtarıldı. Çetenin iki üyesini yakalayıp gözaltına alan polisin kaçırma olayına karışan çete üyesi 2 Suriyeli'yi yakalama çalışmaları ise devam ediyor.

Olumsuz metinlere bakıldığında genel olarak toplumsal sorunlar görsel öğelerle açıklanmaya çalışılmıştır. Şekil 1 'de yer alan haberin içeriği incelendiğinde sığınmacılar toplumsal, ekonomik sorunların ana nedeni olarak tanımlanmıştır. Aynı zamanda çoğu sığınmacının adli olaylara karışması sonucunda halkın Suriyelilere olan nefret söylemlerini arttırmaktadır. 
Şekil 2. Türk doktorların elinde şifa bulan Suriyeli bebek (Yeni Şafak)

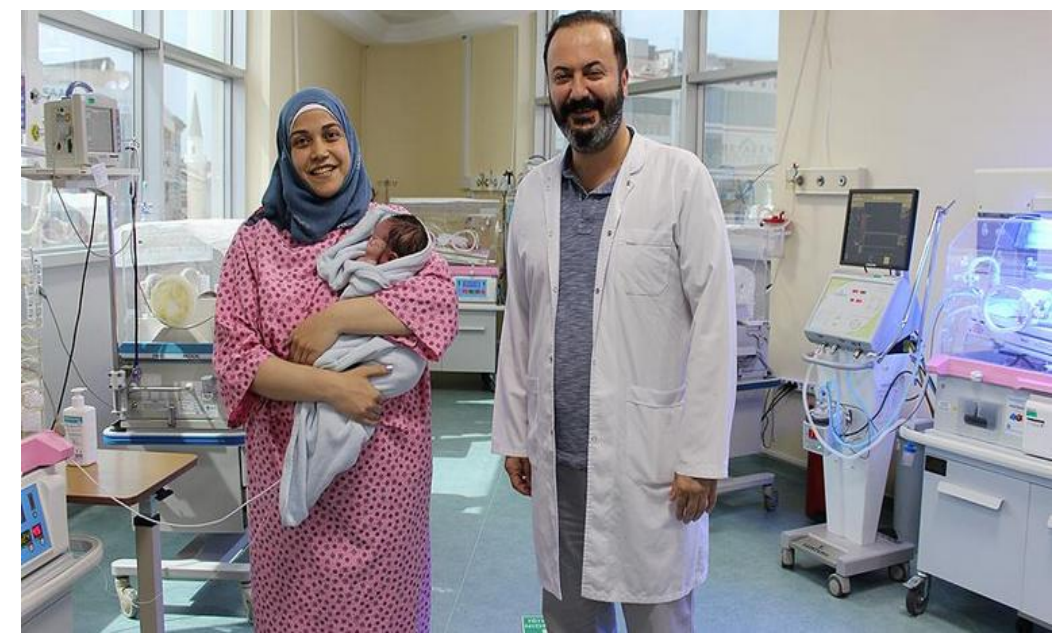

Kaynak: (www.yenisafak.com, 2017, E. T.: 19.02.2018)

Yemek borusunun bir kısmının oluşmaması şeklinde tanımlanan özofagus atrezisiyle dünyaya gelen Suriyeli bebek, henüz bir günlükken Esenyurt Necmi Kadığlu Devlet Hastanesi'nde yapılan başarılı ameliyatla sağlığına kavuştu. Hastanenin Başhekimi Yrd. Doç. Dr. Ahmet Atilla Yılmaz şunları da belirtti: Hastanemizde çok gayretli, gerçekten bilgi, birikim ve tecrübesini yansıtmak isteyen bir ekip var. Biz de arkadaşları biraz motive ederek, çalışma koşullarını iyileştirerek katkı sağlamaya çalışıyoruz. Özellikle beyin, gastrointestinal tümörler ve çocuk cerrahi branşında yeni doğanların hemen hemen tüm hastalıkları ameliyatla tedavi ediliyor ve eğitim hastanesi olmamasına rağmen hastanemizde bir eğitim hastanesi ayarında ameliyatlar yapılıyor. Bu noktada bu hastanede yöneticilik yapmaktan çok memnunum. Biz de bu hizmetlerin kalitesini daha artırarak devam ettirmek istiyoruz".

$\mathrm{Bu}$ haber metininde olumlu söylemler yer almaktadır. Bunlar ideolojik yaklaşımın temelini de oluşturmaktadır. Sığınmacıların ülkeye yeni istihdam sağlayabileceği, aynı zamanda onlara yapılan yardımların insanlık görevi olduğu belirten yaklaşımlar bulunmaktadır. Bu da kamuoyu üzerindeki olumlu algıyı oluşturan ve insaniyeti artırmaya yönelik teşvik edici içeriklerdir. Aynı zamanda bazı araçlarda mültecilerin yaşam koşulları, yaşadıkları zorluklardan bahsedilmiştir. $\mathrm{Bu}$ sayede onları biraz olsun anlamak ve merhameti artırmak amaçlanmıştır.

Şekil 3. Milletimizin mültecileri duygulandırması (İnternet Haber)

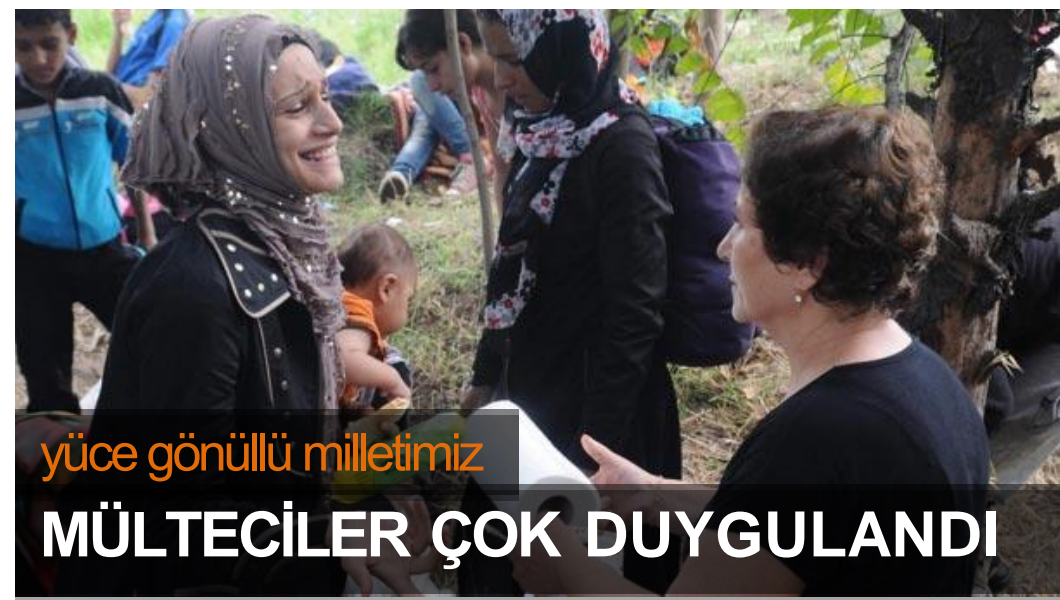

Kaynak: (http://www.internethaber.com,2015/, E. T.: 19.02.2018)

Esenyurt'ta yaşanan bir olay milletimizin yardımseverliğini ve cömertliğini bir kez daha ortaya koydu. Esenyurt'lular Suriyeli mültecileri sahipsiz bırakmadı. Avrupa halkı mülteciler konusunda sınıfta kalırken dünya Türkiye'nin ve Türk halkının cömertliğini ve yardımseverliğini bir kez daha gördü. Esenyurt'ta bugün yaşanan bir olay halkımızın ne kadar yüce gönüllü olduğunu bir kez daha ortaya çıkardı. Sı ğınmacı grup içinde yer alan kadın ve çocuklar otoyol kenarındaki yeşillik alandaki bir avuç gölgeliğe sığındı. Konutlarının hemen önünde 
yaşanan bu drama çevre sakinleri duyarsız kalmadı. Esenkent sakinlerinden iki kadın evde pişirdikleri yemekleri sığınmacılara götürdü. Vatandaşlarımızın bu davranışı Suriyeli mültecileri duygulandırdı.

Barış gazetecilerin önemli isimlerinden Jake Lynch ve Annabel McGoldrick göre, dezavantajlı grupların farklılıklarından öte, ortak platformda buluşma olasılığının mümkün olduğunu anlatan, barışçıl, demokratik ve insan haklarından yana çözüm odaklı haberler yapılmalıdır. Bu haber metininde de halkımızın mültecilere karşı olan barışçıl ve çözüm odaklı yaklaşımı konu alınmıştır. Halkımızın Suriyelilere karşı olan duyarlı davranışlarına yer verilmiştir. Buna karşılık özellikle mülteci kadınlar çok duygulanmış ve bölge halkına ne kadar teşekkür ettikleri belirtilmiştir.

Şekil 4. Küçük Suriye Esenyurt (Gazete Damga)

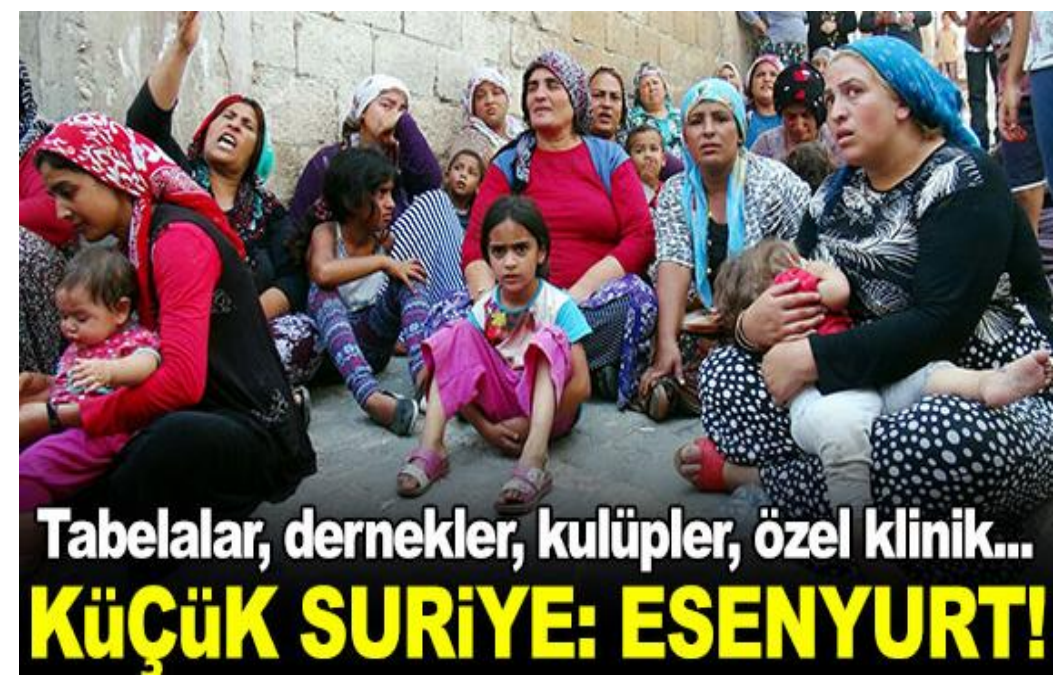

Kaynak: (www.gazetemistanbul.com, 2014/, E. T.: 19.02.2018)

Bu haber manşetinden anlaşılacağı gibi bazı haber metinleri tarafsız şekilde yalnızca bilgiyi karşı tarafa anlatır şekilde verilmiştir. Haberler ayrıntılı olarak incelendiğinde Suriyelilerin Esenyurt’ta kendi bölgelerini oluşturduklarını belli eden manşetlere rastlamak mümkündür.

\section{MÜLAKAT VE MEDYA ANALIZ/BULGULAR}

İstanbul'un Esenyurt bölgesinde yapılmış olan bu araştırmamız sonucunda elde edilmiş olan bulgularla, ülkemiz geneli için analiz yapılmıştır. Yapılan röportajların ve medyada çıkan haberlerin bulguları aşağıdaki gibidir:

\section{Suriyelilerin Görüş ve Beklentileri;}

- Yapılan röportajlarda Suriyelilerin bir kısmı Türkiye'de oldukları için memnun olduklarını, burada mülteci gibi değil de misafir gibi karşılandıklarını ifade etmektedirler.

- Suriyelilerin dile getirdiği sorunlar arasında en dikkat çekenleri işsizlik, emek sömürüsü ve eğitim konusunda olmuştur. Çoğunluğu kağıt toplayarak geçinen ve diğer alanlarda çalışan Suriyeliler emek sömürüsünden şikayet etmektedirler.

- Savaş bittiğinde ülkesine geri dönmek isteyen Suriyelilerin sayısı da fazladır. Savaşın bitmesini ne kadar arzulasalar da bir kısmı da bu konudaki umudunu yitirmek üzeredir.

- Suriyeli çocukların ve ailelerinin en çok kaygılandıkları durum yarım kalan eğitimleri olmuştur. Türkiye'deki Türkçe eğitim, vatandaşlığın olmaması ve çalışmak zorunda olmalarından dolayı Suriyeli çocukların çoğunluğu eğitimini yarıda bırakmak zorunda kalmıştır. Türkiye'deki Suriyelilerin ancak yaklaşık yüzde 15 'i eğitimlerine devam edebilmektedir.

- Yapılan çalışmada bir kısım Suriyeli güvenlik sorunlarından bahsetmiş̧ir. Özellikle Esenyurt'u güvenlik açısından iyi bulmadıklarını ifade edenler kiraların uygun olmasından dolayı ve zorunluluktan burada yaşadıklarını belirtmişlerdir.

- Diğer bir sorun da dil problemi olarak karşımıza çıkmaktadır. Suriyeliler Türkçe bilmediklerinden dolayı yerel halk ile aralarında bazı kopukluklar olduğunu söylemişlerdir. 
- Üniversite eğitimini yarıda bırakmış olan Suriyeliler bu konuda epey endişelilerdir. Ya ülkelerine dönüp ya da yurtdışına giderek eğitimlerini tamamlamak istediklerini belirtmişlerdi. Gerekçe olarak Türkiye'deki işsizlik ve gelecek kaygısını vurgulamışlardır.

- Yerel halk tarafindan ötekileştirildiklerini ifade eden Suriyeliler konunun insani boyuttan çok siyasi olarak ele alındığını ifade etmişlerdir.

- Vatandaşlık hakları olmadığı için sağlık konusunda da zorluk çektiklerini belirten Suriyeliler bulunmaktadir.

\section{Türklerin / Yerel Halkın Suriyeliler Konusunda Görüşleri;}

- Esenyurt'ta yapılan 100 röportajda yerel halkın üzerinde durduğu Suriyeliler hakkındaki ana söylemler: işsizlik, güvensizlik ortamı, dil uyumsuzluğudur. Kitlesel göç hareketlerinde kent halkını rahatsız eden ve olumsuz algının oluşmasına neden olan sebepler içerisinde "iş kaybetme" ve "iş gücü" alternatifinin artması sonucu rekabet ve gelir seviyesindeki düşüş" gelmektedir. İşverenlerin yerel halktan daha ucuza çalışan Suriyelileri işe alması halkı huzursuz etmekte ve toplumsal gerginliği artırmaktadır.

- Bölgede "Türkiye ilk önce kendi vatandaşlarına öncelik vermelidir" şeklinde görüşlere rastlanmaktadır.

- Yerel halk Suriyelileri hırsızlık, gasp, kamu malına zarar verme, sokakta kadınlara huzursuzluk verme ile ilişkilendirmiştir.

- Bölge insanı Suriyelilerin gelmesiyle huzurun bozulduğunu, hırsızlık olaylarının arttığına dair pek çok şikâyeti dile getirmiştir.

- Kültürel farklılıklar nedeniyle, zaman zaman Suriyelilerin varlığını problem olarak niteleyenlerin sayısı da fazladır. Burada bir arada kardeşçe yaşama yaklaşımı yaygın olarak gözlemlenememiştir.

- Kent halkı içersinde Suriyelilerin varlıklarından rahatsız olan ve ülklerine gitmeleri gerektiğini belirtenler kadar, onlara destek olunması ve dışlanmaması gerektiğini söyleyenler de olmuştur.

- Yerel halkın Suriyelilerle ilişkilendirildiği diğer bir konu ise dilenciliktir. Yerel halk Suriyelilerin gelmesiyle daha da artan dilencilik konusunda kendini rahatsız ve güvensiz hissetmektedir. Dilencilik konusunda daha fazla önlemin alınması gerektiği yargısı da yaygındır.

- Halkın değindiği diğer bir konu ise sağlık alanındadır. Araştırmada ülkemizde Suriyelilere sağlık alanında öncelik verildiğini, Türkiye'nin ilk önce kendi halkına önem ve öncelik vermesi gerektiğini belirten yargilar bulunmaktadır.

- Büyük çoğunluk Suriyelilerin misafir olduğunu ve artık ülkelerine dönmeleri gerektiğini söylemiştir. Aynı zamanda halk kendi kültürüne yakın Suriyelileri biraz daha fazla benimserken diğerlerini dışlamaya yönelmişlerdir.

\section{SONUÇ}

İstanbul'un Esenyurt bölgesinde yapılmış olan bu araştırmamız sonucunda elde edilmiş olan bulgularla ülkemiz geneli için değerlendirmemiz sonucunda; 2011 yılından bu yana patlak veren Suriye savaşıyla birlikte tüm Türkiye'de olduğu gibi İstanbul iline de hızlı bir göç dalgası olmuştur. Suriyelilerin en çok göç ettiği bölgelerden biri olan Esenyurt ilçesinde savaşın uzun sürmesi nedeniyle gelenlerin kalıcı olarak burada kalması bölgede ekonomik ve sosyo-kültürel açıdan büyük etkiler yaratmıştır. İlk olarak, Suriyelilerin ülkemizdeki kalış süreleri konusunda gerçekçi tespitler yapılmalıdır. Türkiye'de kalıcı nüfus haline gelen Suriyelilerin, toplum üzerinde oluşturduğu olumsuz etkileri azaltacak önlemler alınmalıdır. İkinci olarak kapsamlı Suriyeli mülteci politikası hazırlanmalıdır. Bu şekilde yerel halk üzerinde oluşan olumsuz algıyı önlemek amaçlanmalıdır.

Esenyurt'a Göçlerin Ekonomik ve Sosyo-Kültürel Etkilerine bakıldığında, Suriyeli mültecilerin Türkiye ekonominisi üzerindeki etksinde risk ve firsatlar bir aradadır. Bölgede ev kiraları rakamlarında artış gözlemlenmiştir. Bazı ev sahipleri bu durumu firsata dönüştürmüştür. Bir diğer etkisi kuşkusuz iş gücü anlamındadır. Suriyeliler kaçak iş gücü olarak çalışmaya başlamışlardır ve bu da işveren açısından önemli oranda kazanç sağlamıştır. Ancak bu durum olumsuz sonuçlar doğurmuştur. Özellikle küçük işletmelerde kaçak işçi çalıştırmanın yaygınlaşmasıyla, haksız rekabet ortamı oluşmasına zemin hazırlamıştır. Yerel halk iş firsatlarının ellerinden alındığını düşündüğü bu durum genel olarak memnuniyetsizlikle sonuçlanmaktadır. Suriyeliler genelde düşük ücretle çalışmayı kabul ettikleri için işverenler tarafından öncelikli tercih edilir hale 
gelmiştir. Yerel halk artık Suriyelileri ekonomik tehdit olarak görmekte ve onlara yer yer tepki gösterdiği görülmektedir. Suriyelilerin dükkan açmaları, küçük işletmeler kurmaları, üretim ve ticarete katkı sağlamaları ve bu işletmelerin büyük bir çoğunluğunun kayıt dışı olması nedeniyle yerel halk rahatsızdır.

Tüm Türkiye'de olduğu gibi Esenyurt'ta da Suriyeliler, toplumsal entegrasyon sürecinde sorunlar yaşamaktadır. $\mathrm{Bu}$ sorunun en önemli nedeni kuşkusuz yerel halk ve Suriyeliler arasındaki dil, kültür, yaşam tarzının farklı oluşudur. Ayrıca gelen mültecilerin düzensiz ve çarpık yapılaşması, kadın ve çocuk istismarlarının yaşanması, mezhepsel kutuplaşmalar toplumsal etkilerdendir. Bölgede yaşayan Suriyeliler evlerde birkaç aile olarak da kalabilmektedir. Bu da koşulların daha olumsuz olmasına neden olur. Bazı ev sahipleri daha çok kira alabilmek için kaçak yapılar yapabilmektedir. Mülteciler kendilerine yaşam alanı bulabilmek adına buralarda ya da metruk binalarda yaşama çabasına girmektedirler. Bu da çarpık yapılaşmayı ve gecekondulaşmayı teşvik etmektedir.

Sığınmacıların bölgede yarattığı bir diğer toplumsal sorun çocuk işçiliğidir. Suriyeli çocukların çok küçük bir bölümü eğitimlerine devam edebilmektedir. Diğerleri ailelerinin geçimine katkıda bulunabilmek amaciyla çalışmaya yönelmiştir. Paraya ihtiyaçları olması sebebiyle kağıt toplama, tekstilde ortacılık gibi kayıt dışı enformel sektörde çalıştırılmaktadırlar. Bazıları da sokak başlarında dilencilik yapar ya da mendil satmaktadır.

Bölgedeki diğer bir sorun ise demografik yapının değişmesiyle bunun yaratmış olduğu güvensizlik hissidir. Yerel halk özellikle mülteciler geldikten sonra kendisini rahatsız hissetmektedir. Misafir olarak geçici bir süreliğine Türkiye'ye gelen Suriyelilerin kalıcı bir nüfus haline dönüşmesi sebebi ile yerel halkın daha çok tepkisini toplar hale gelmiştir. Yerel halk Suriyelileri bir tehdit olarak algılamaktadır.

Halkın büyük çoğunluğunun Suriyelileri ötekileştiren ve varlığını sorun olarak niteleyen söylemleri bulunmaktadır. Siyasette yaşanan çatışmalar halkın Suriyelilere olan baskısını da etkilemektedir. Aynı zamanda kent nüfusuyla bir arada yaşamayı sürdürmeye çalışan mülteciler için uyum süreci daha zorlaşmaktadır. Olumsuz koşullarda yaşamaları her türlü suça zemin hazırlayabilir. Çevresel etkilere bakıldığında çarpık yapılaşmanın yanında bölgedeki yerel halk dışındaki nüfusta arttıkça kent kirliliği, alt yapı yetersizliği, çöp gibi sorunlara yol açmaktadır. Belediyelerin hizmet kapasitesinde ve çözüm üretiminde yetersizlikler olmaktadır.

Göç etmenin Suriyeliler açısından olan toplumsal etkilerine bakılacak olunursa kuşkusuz en çok etkilendikleri konu çocukların eğitimidir. Bu durum çocuklar ve aileleri için büyük sıkıntı teşkil etmektedir. Bu süreçte eğitimine devam edemeyen Suriyeli çocuklar kültürel etkinliğini tamamen kaybedip ilerde kayıp bir kuşak oluşturabilir. Yaşam koşullarının zor olmasıyla şiddete eğilimleri arasında doğru bir orantı vardır. Suriyelilerin yaşadıkları olumsuz koşullar sebebi ile kışkırtmacı bir durum içerisinde bulunma halinde yerel halkın nefretini daha çok kazanabilir.

Sağlık koşulları açısından bakıldığında yerel halkın gözünde mülteciler sorun teşkil etmektedir. Bölgede belediyeye kayıt yaptırmış olan Suriyeliler devlet hastanelerinden ücretsiz faydalanabilmektedir. Hastanelerde kapasite sorunu yaşanmaktadır aynı zamanda mülteciler zaman zaman Türkiye'de daha önce görülmemiş olan hastalıkların da oluşmasına zemin hazırlayabilmektedir.

Suriyeli mültecilerin, Türkiye siyasetine olan etkisi yadsınamaz bir gerçektir. Yerel halk ile gerilimlerin artması, yerel halkın güvenlik kaygısı ve siyasetteki kutuplaşma mevcut etkilerdendir. İçinde bulunulan siyasi ortam Suriyelilere bakışı da etkilemektedir. Yerel halkın bir kısmı müsamaha gösterirken diğer kısım ise "ülkelerine dönüp kendi ülkeleri için savaşmalılar" düşüncesi temelinde tepkiler gösterebilmektedir. Bu zaman zaman halk arasında da çatışmalara yol açabilmektedir. Bir diğer sorun ise güvenliklerini sağlama amacındaki bazı Suriyelilerin kendi aralarında örgütlenebilmesidir. Bunun sonucunda iki toplum arasında kutuplaşma daha çok artırmaktadır. Bu şekilde yerel halkın en büyük korkusu eğitim alamayan, dışlanıp kimlik bunalımı geçiren, zor koşullarda ve düşük gelir seviyesindeki mültecilerin uzun vadede pek çok suçun kaynağı olacağıdır. Bu da gelecekte yeni güvenlik risklerinin oluşmasına zemin hazırlamaktadır.

Medya, toplumsal algı üzerinde önemli bir etkiye sahiptir. Yapılan haber analizleriyle üç ana konunun somutlaştırıldığı söylenebilir. İlk olarak, Suriyeli mültecilerin varlığını "tehdit" ve "risk" unsuru olarak çerçeveleyen haberler sığınmacıların getirdikleri ekonomik yük ve güvenlik sorunu ile ilişkilendirilmektedir. İkinci düzlemde, hükümetin mültecilere yönelik açık kapı politikasını açıkça ya da örtük biçimde onaylayan bir söylem biçimiyle, Suriyelilerin Türkiye'deki varlığı, hak ihlalleri veya meselenin insani boyutu göz önüne alınmaksızın, harcanan paralar, yapılan yardımların miktarı ve mültecilerin sayısına yapılan vurgularla "nesnelleştirilmektedir”.Üçüncü olarak, mültecilerin Türkiye deki varlığını, içinde bulundukları koşulları ve kamuoyunda mültecilerin kentlerdeki "aşırı görünürlügüne" yönelik tepkileri "duygusallaştıran" bir söylemsel düzlem karşımıza çıkmaktadır. Soruna karşı"vicdani çözümler” ileri sürülmekte, yardımlaşmanın ve dayanışma 
göstermenin önemi vurgulanmakta, ancak sorunun toplumsal - politik nedenlerine veya sonuçlarına yönelik herhangi bir ima, bu haberlerin kurduğu çerçeve içinde yer bulamamaktadır.

Bütün bu çıkarımların ışı̆̆ında öneriler olarak: Ülkemize gelen her Suriyeli mültecinin parmak izleri ve fotoğrafları alınarak kayıt edilmeleri gereklidir. $\mathrm{Bu}$ şekilde giriş çıkışlar da kontrol altına alınabilir ve Suriyelilerin demografik yapıları tam olarak belirlenebilir. Tüm kurumlar Suriyelilerin entegrasyonu için kendi alanlarında çalışmalar yapabilir. İlk olarak mülteciler Türkçe öğrenmeye teşvik edilmelidir. Bunun sonucunda yerel halkla da ilişkileri artacak olup uyum süreci de kolaylaşacaktır. Suriyelilerin yoğun olarak yaşadığı belediyelerdeki çevresel sorunların giderilmesi için hizmetler ve bu hizmetler için ayrılan payların artırılması gerekir. Belediyeler bunun için ek ekonomik destek sağlamalıdır.

Suriyeli çocukların bir kısmı hala okula gidememektedir. Bu çocukların okula gitmesi, gidenlerin ise daha kaliteli bir eğitim alması için Milli Eğitim Bakanlığı'nın kapsamlı çalışmalar yapması gerekir. Çocukların eğitim ihtiyaçlarının karşılanması, öğrencilerin Türkçe öğrenmesine yönelik çalışmalar yapılması, çocuklara psikolojik destek sağlanması önerilebilir.

Suriyelilere iç barışı bozmayacak şekilde istihdam sağlanmalıdır. Onların çalışma hayatıyla ilgili mevzuat hazırlanıp hayata geçirilmelidir. Her firma belirli oranda Suriyeli çalıştırmalı ve bu sayının üzerine çıkılmamalıdır. Çalışma şartları iyileştirilerek mağduriyetleri giderilebilir. Kayıt dışı istihdamın bu şekilde önüne geçilebilir. Yapılan bu ana tespitler 1şığında önerilerin hızla hayata geçirilmesi faydalı olabilir. Böylesi bir durum ülkemizin istikrar ve huzurun sağlanmasına katkıda bulunabilir.

\section{KAYNAKÇA}

BARNES, Donella M. (2001), "Mental Health Screening in A Refugee Population: A Program Report", Journal Of Immigrant Health, S.3(3), ss.141-149.

BETER, Önder (2006), Sınırlar Ötesi Umutlar Mülteci Çocuklar, SABEV Yayınları, Ankara.

BUZ, Sema (2008), "Türkiye'deki Slğınmacıların Sosyal Profili", Polis Bilimleri Dergisi, S.10(4), ss.1-14.

DENIZ, Taşkın (2014), "Uluslar Arası Göç Sorunu Perspektifinde Türkiye", Tsa Dergisi, S.18(1), ss.175-204.

ERDER, Sema (1986), Refah Toplumunda “Getto" ve Türkler, Teknografik Matbaacilık, İstanbul.

ERDOĞAN, M. Murat, KAVUKÇUER, Yudum ve ÇETINKKAYA, Tuğçe (2017), Türkiye'de Yaşayan Suriyeli Mültecilere Yönelik Medya Algısı, Özgürlük Araştırmaları Derneği Yayını, Ankara.

GÜÇTÜRK, Yavuz (2014), Sürgün ile Savaş Arasında Suriyeli Mülteciler, Siyaset, Ekonomi ve Toplum Araştırmaları Vakfı (SETA) Yayını, Ankara. http://setav.org/tr/5-soru-surgun-ile-savas-arasindasuriyeli multeciler/yorum/18059/ (Erişim Tarihi: 10.02.2018).

GÜN, Zübeyit (2006), "Göç Üzerine Psikolojik Çalışmalar, Yöntemsel Sorunlar ve Çözüm Önerileri", Türk Psikoloji Bülteni, S.12(38), ss.27-41.

GÜVENÇ, Bozkurt (1999), İnsan ve Kültür, Remzi Kitabevi, İstanbul.

İÇDUYGU, Ahmet, ERDER, Sema ve GENÇKAYA, Ömer Faruk (2014), Türkiye'nin Uluslararası Göç Politikaları 1923-20023: Ulus Devlet Oluşumundan Ulus Ötesi Dönüşümlere (MireKoç Raporları), Koç Üniversitesi Koç Araştırmaları Merkezi Yayını, İstanbul.

KARPAT, Kemal (2010), Osmanlı’dan Günümüze Etnik Yapılanma ve Göçler (Çev., Bahar Tırnakçı), Timaş Yayınları, İstanbul.

LI, Wei ve TEIXEIRA, Carlos (2007), "Introduction: Immigrants and Transnational Experiences in World Cities", Geo Journal, S.68, ss.93-102.

SETA - SIYASET, EKONOMI VE TOPLUM ARAŞTIRMALARI VAKFI (2018), Kurumsal Web Sayfası, http://www.setav.org/ (Erişim Tarihi: 10.02.2018).

UZUN, Aytül (2015), "Günümüzün Sosyal ve Ekonomik Sorunu Olan Suriyelilerin Mülteci ve Ekonomi Hukuku Bakımından Değerlendirilmesi", Ankara Barosu Dergisi, S.?(1), ss.107-120.

T. C. İÇIŞLERİ BAKANLIĞI GÖÇ İDARESİ GENEL MÜDÜRLÜĞÜ (2018), Kurumsal Web Sayfası, http:/www.goc.gov.tr/ (Erişim Tarihi: 19.01.2018). 
T. C. İÇiş̧ERİ BAKANLIĞI GÖÇ İDARESİ GENEL MÜDÜRLÜĞÜ (2018), "Suriye", E-Makale, http://www.goc.gov.tr/icerik3/suriye_363_378_4713/(Erişim Tarihi: 10.02.2018).

http://akademikperspektif.com (Erişim Tarihi: 10.02.2018).

http://data.unhcr.org/syrianrefugees/regional.php (Erişim Tarihi: 20.02.2018).

http://www.demokrathaber.org/calisma-hayati/isciler-suriyelilere-yonelik-saldirilara-karsi-yurudu-h37279.html (Erişim Tarihi: 19.02.2018).

http://www.dunyabulteni.net/haber-analiz/334494/suriyede-savasan-taraflar-ve-son-durum-ii/ (Erişim Tarihi: 22.01.2018).

http://www.goc.gov.tr/icerik3/suriye_363_378_4713/(Erişim Tarihi: 19.01.2018).

http://www.ilo.org (Erişim Tarihi: 13.01.2019).

http://www.multeci.org.tr/wp-content/uploads/2016/12/1951-Cenevre-Sozlesmesi-1.pdf （Erişim Tarihi: 12.02.2018).

https://www.afad.gov.tr (Erişim Tarihi: 01.02.2018).

https://www.gazetemistanbul.com/ozel-haber/kucuk-suriye-esenyurt-h46398.html (Erişim Tarihi: 19.02.2018).

www.3rpsyriacrisis.org (Erişim Tarihi: 13.01.2018). 